\title{
Reading between the Lines: The Social Value of Dogoszhi Style in the Chaco World
}

\author{
Evan Giomi (D, Barbara J. Mills, Leslie D. Aragon, Benjamin A. Bellorado, and Matthew A. Peeples
}

Archaeologists have pointed to certain architectural or decorative designs as representing "elite styles" that mark status distinctions. We look at one such style-Dogoszhi-that was applied to several pottery wares across the Chaco World of the northern Southwest. Using a large database of ceramics, we test whether this style comprised an elite style or whether it signaled participation in a broader Chaco social network. We compare the distribution of Dogoszhi style to measures of settlement importance, including site size and network centrality, and we investigate whether this style occurs differentially at Chacoan great houses as opposed to small houses, or by subregion. We also compare its spatial distribution to an earlier style, called Black Mesa style, similarly applied to a number of different wares. Our results indicate that both styles were consistently distributed within Chaco communities (whether great houses or small houses) but variably distributed across subareas and most measures of settlement importance. We conclude that Dogoszhi style was used to mark membership in social networks that cross-cut great house communities, a pattern more typical of heterarchical rather than hierarchical social structures. Such variation questions the uniform category of "elites" and points to the ways that representational diversity may be used to interpret different regional histories and alliances.

Keywords: Chaco, elite style, ceramics, hierarchy, heterarchy

Los arqueólogos han señalado que ciertos diseños arquitectónicos o decorativos representan "estilos de élite" que marcan distinciones de estatus. Observamos uno de esos estilos, el estilo Dogoszhi, que se aplicó a varios artículos de cerámica en todo el Mundo de Chaco del norte del suroeste. Utilizando una gran base de datos de cerámica, probamos si este estilo comprendía un estilo de élite o si señalaba la participación en una red social de Chaco más amplia. Comparamos la distribución del estilo Dogoszhi con las medidas de la importancia del asentamiento, incluido el tamaño del sitio y la centralidad en la red, y si este estilo ocurre de manera diferente en las casas grandes del Chaco frente a las casas pequeñas, y por subregión. También comparamos su distribución espacial con un estilo anterior, llamado estilo Black Mesa, aplicado de manera similar a una serie de cerámica diferentes. Nuestros resultados indican que ambos estilos se distribuyeron consistentemente dentro de las comunidades del Chaco (ya fueran casas grandes o pequeñas) pero distribuidos de manera variable entre subáreas y la mayoría de las medidas de importancia de asentamiento. Concluimos que el estilo Dogoszhi se utilizó para marcar la pertenencia a las redes sociales que atraviesan grandes comunidades de casas, más típicas de estructuras sociales heterárquicas que jerárquicas. Tal variación cuestiona la categoría uniforme de "élites" y señala las formas en que la diversidad representacional puede usarse para interpretar diferentes historias y alianzas regionales.

Palabras clave: Chaco, estilo de élite, cerámica, jerarquía, heterarquía

Evan Giomi (egiomi@email.arizona.edu, corresponding author) and Barbara J. Mills $\square$ School of Anthropology, University of Arizona, 1009 E. S. Campus Drive, Tucson, AZ 85721-0030, USA

Leslie D. Aragon $\square$ Desert Archaeology Inc., 3975 N. Tucson Boulevard, Tucson, AZ 85716-1037, USA

Benjamin A. Bellorado a Crow Canyon Archaeological Center, 23390 Road K, Cortez, CO 81321, USA

Matthew A. Peeples $\square$ School of Human Evolution and Culture Change, Arizona State University, PO Box 872402, Tempe, AZ 85287, USA

American Antiquity 87(1), 2022, pp. 100-123

Copyright (C) The Author(s), 2021. Published by Cambridge University Press on behalf of the Society for American Archaeology. This is an Open Access article, distributed under the terms of the Creative Commons Attribution licence (http://creativecommons.org/licenses/by/4.0/), which permits unrestricted re-use, distribution, and reproduction in any medium, provided the original work is properly cited.

doi:10.1017/aaq.2021.50 
7 "Chaco World" is an archaeological pattern covering a large area of the North American Southwest between roughly $\mathrm{AD} 800$ and 1150 , and it is centered on the eponymous Chaco Canyon (Figure 1). The growth and extent of this pattern is primarily measured by the distribution of architectural features identified as distinctly Chacoan, including formal roads, great kivas, great houses, and specific masonry styles (Judge 1991; Kantner 2003a, 2003b; Lekson 2007; Plog 2015). Increasing social differentiation also helps to define the Chaco World, particularly the existence of elites at Pueblo Bonito starting in the AD 800s (Plog and Heitman 2010), and later at Aztec in the Middle San Juan area (Lekson 2015). Another distinguishing feature of the Chaco World was the acquisition of longdistance goods from as far away as Mesoamerica (Crown and Hurst 2009; Nelson et al. 2017; Watson et al. 2015) and large-scale regional procurement of other materials, such as turquoise (e.g., Thibodeau et al. 2012), wood (Guiterman et al. 2016), flaked stone (Cameron 2001), and ceramics (Cameron and Toll 2001).

The spread of styles strongly associated with Chaco Canyon itself-including architectural layouts, masonry styles, and ceramic decorative styles - are other ways that archaeologists have looked at both social connectedness and social differentiation within the Chaco World. If style is defined as a choice or "a way of doing things" (Hegmon 1992:518), then the inherent sociality of learning and doing style makes it suitable for understanding social connectedness from archaeological materials. Likewise, variation in style allows for some kinds of highly visible styles to serve a communicative function in culture, including marking participation in social groups and social differences (Carr 1995). Yet, how style is variably employed across different statuses and their related identities needs to be demonstrated rather than assumed. In this article, we look at how style was employed in contexts of differential statuses to investigate how inequality and region-wide styles intersect.

In the Chaco World, a particular ceramic decorative style known as Dogoszhi style cross-cuts ceramic types and zones of ceramic production and has been argued to indicate participation in the broader Chaco network (Judge 1991:27-28; Lekson 2007; Plog 1995, 2015:10; Toll 1985:215-216). Neitzel (1995) explicitly tied Dogoszhi style to elites in Chaco Canyon and inferred that the regional distribution of the style stemmed from emulation by other elites. According to this interpretation, the distribution of the style is the result of its association with elites in Chaco Canyon and was a means of marking social status. Others reject the proposition that Dogoszhi-style ceramics represent a Chacoan elite style, and they suggest instead that the widespread distribution of Dogoszhistyle ceramics within the Chaco World indicates that the style acted as a marker of community membership that was more broadly shared (see, especially, Toll et al. 1992). Both sides of this debate cite the high percentage of Chaco cylinder jars decorated in Dogoszhi style as one of the primary lines of evidence. Even before Crown and Hurst's (2009) finding that cylinder jars were used for the preparation of cacao beverages, archaeologists recognized the restricted distribution of these jars to Chaco Canyon and especially within Pueblo Bonito's Room 28 (Neitzel 1995; Toll 1985, 1990). Room 28 was ritually terminated, adjacent to other ritual storage rooms, and it was two rooms away from the densest concentration of elite burials in the northern Southwest (Crown 2018, 2020). The use of the style on special forms such as cylinder jars is in contrast to the dominance of Dogoszhi style on other vessel forms used in everyday practice at a variety of site types, including both great and small houses, which some researchers suggest is more indicative of broader community membership rather than of elite status (Toll 1985; Toll et al. 1992).

These ideas fall on a continuum of interpretations about what constitutes an elite style and how such styles may or may not be produced and used by members of the larger community. In many areas of the world, elite styles are intentionally restrictive in order to mark who is an elite, especially through clothing and house styles (Feinman and Neitzel 1984). In societies with clearly demarcated hierarchies, such trappings of prestige are used to legitimize and perpetuate the existing social order. But even within state societies, such as the Inka, elite 


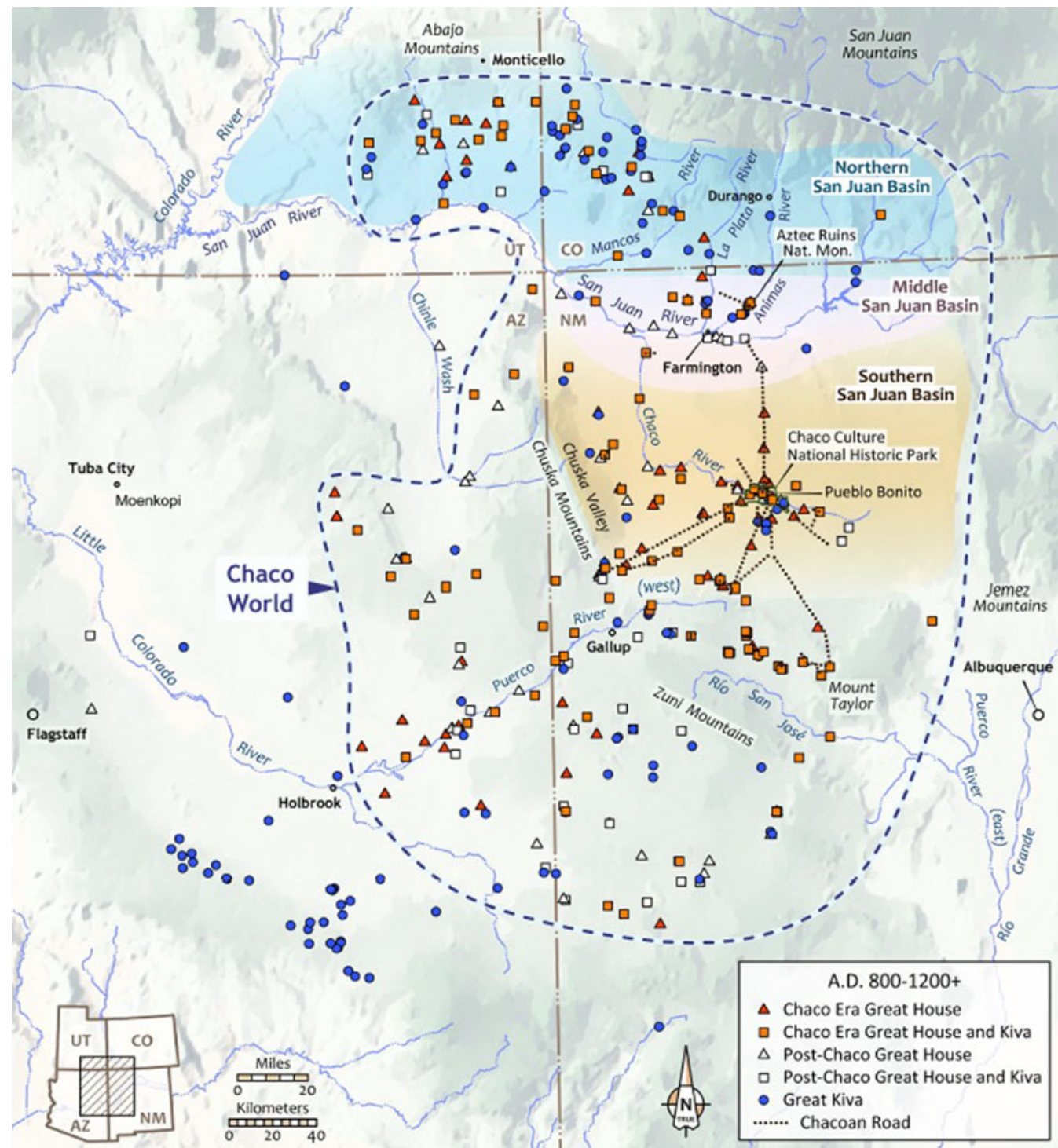

Figure 1. Map of great kivas and great houses that define the Chaco World, as well as regions mentioned in the text (adapted from Mills et al. 2018). (Color online)

styles were replicated to various degrees through multiple social strata (Morris 1995). In the Monte Albán polity, demand for highly valued Crema ware by subordinate elites in outlying areas was met by encouraging production outside the center (Elson and Sherman 2013). In the Maya area, it has been suggested that some artifact styles were strategically and widely used by elites in two ways: (1) to promote shared identities among elites, and (2) to encourage an inclusive identity among all members of the society to support emerging or established elites (Schortman et al. 2001). In the latter strategy, the presence of widespread styles may be evidence of elites seeking self-legitimacy by including other elites and even nonelites in social, ritual, and political practices that fostered cooperation and solidified alliances to create networks of power (Schortman 2014).

In this article, we revisit the proposition that Dogoszhi style is an elite style by comparing the distribution of ceramics decorated with this 
style across the Chaco World. Proponents of Dogoszhi as an elite style have largely based their argument on smaller-scale studies in the Black Mesa area to the west of the Chaco World (Neitzel and Bishop 1990; Plog 1989, 1990). Only two larger-scale, regional analyses have been previously conducted. Neitzel (1995) used whole vessels from 10 excavated great houses and found that higher percentages of Dogoszhi-style vessels were generally correlated with the largest sites in the settlement hierarchy, which she interpreted as evidence that it was an elite style. In a larger sample of sherd assemblages from great and small houses, Toll and colleagues (1992) found that the percentages of Dogoszhi-style ceramics were highly variable and present at both site types. They suggested that, like its predecessor, Black Mesa-style ${ }^{1}$, the use of Dogoszhi style indicates regional-scale communication and social ties to multiple areas, which would have been an adaptive strategy to ameliorate local crop failures. In both studies, sites and assemblages with different chronological placement were pooled, and in the case of Toll and colleagues' analysis, only two sites from Chaco Canyon were included-the great house of Pueblo Alto and one small house (29SJ627). Later compositional analysis of Dogoszhi-style vessel temper and clay found little evidence for centralized production (Neitzel et al. 2002). Results instead indicate production in a diversity of regions, with distribution cutting across these zones of production.

The increasing availability of regional databases, particularly the Chaco Social Networks database used in this study, now allows us to address the distribution of Dogoszhi style at the macroscale of the entire Chaco World. We look at a large sample of ceramics from great houses and great kivas, as well as a group of outlier communities that includes both great and small houses. We employ a consistent chronological tool based on the dating of individual types and divide each assemblage into 50-year intervals (Roberts et al. 2012). If Dogoszhi-style ceramics were a component of an elite style, they should be differentially distributed across the Chaco World. In particular, they should be found in higher proportions in contexts associated with elite activities (including residence or ceremony) relative to nonelite contexts, and also in greater proportions at great houses and great kivas in central Chaco over more distant outliers. This should be true at both the community and regional scales, with a higher proportion of elite goods at socially prominent sites within the settlement system relative to less prominent sites (Neitzel 1995:397). By contrast, if Dogoszhi-style ceramics were markers of membership in the broader Chaco World, they should be distributed relatively homogenously across the entire region with sharp boundaries marking edges with other regions outside the Chaco World (Neitzel 1995:397; Plog 1995:372; see Hegmon et al. [2021] for a southern Southwest example). In this study, we look at the distribution of Dogoszhi style over several chronological periods and assess whether the distribution of the style is related to settlement size, the importance of settlements in terms of centrality or position within the overall network, or proximity to Chaco Canyon. We also examine the overall homogeneity or heterogeneity of the distribution of Dogoszhi-style ceramics within the broader Chaco World in comparison to the earlier Black Mesa style.

\section{What Is Dogoszhi Style?}

Dogoszhi style is found on ceramic vessels across the northern Southwest and is especially prevalent during the Pueblo II (AD 900-1150) period. In Chaco Canyon assemblages, it peaks in the century between AD 1020 and 1120 (Toll and McKenna 1997:Table 2.11B), which is also when the Chaco World reached its maximum extent (Mills et al. 2018). The style is characterized by an all-over design of rectilinear or curvilinear elements filled with parallel lines, or hachure (Figure 2). Dogoszhi style cross-cuts different wares, which are defined in the Southwest on the basis of suites of technological attributes including paste color, temper type, slip color, and paint types. Such cross-cutting is the basis for Colton's $(1943,1953)$ concept of "analogous types"-types that are technologically distinct but that share a common design repertoire, similar to what have been called "horizon styles" in other areas of the world.

The earliest example of a southwestern ceramic type with a predominantly hachured 


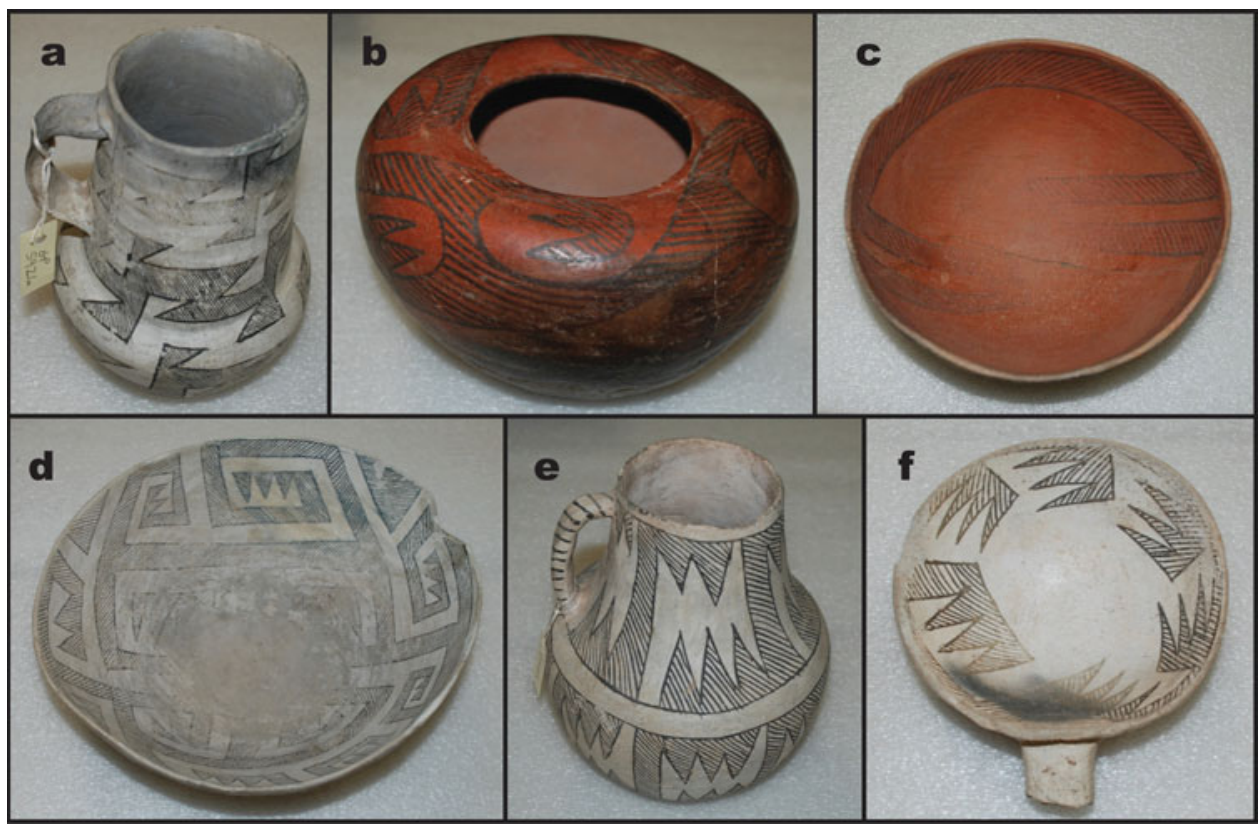

Figure 2. Examples of vessels of different wares decorated in Dogoszhi style: (a) Chaco Black-on-white (GP 5926); (b) Tusayan Black-on-red (3742); (c) Tusayan Black-on-red (GP 3385); (d) Gallup Black-on-white (GP 42594); (e) Gallup Black-on-white (GP 1624); (f) Gallup Black-on-white (04254) (Arizona State Museum, University of Arizona collections). (Color online)

design comes not from the northern Southwest but from the Hohokam World. Early Snaketown Red-on-buff and Late Snaketown Red-on-buff, both part of the Middle Gila Buff Ware sequence, date to $\mathrm{AD} 700-730$ and 730-750, respectively (Heidke and Ownby 2015; Wallace 2001), although the connections between these designs and later designs on the Colorado Plateau have not been investigated in detail. In the Ancestral Pueblo area, the first black-on-white ceramic type with Dogoszhi-style design is Brimhall Black-on-white of the Chuska White Ware sequence, which was made between AD 900 and 1070 (Windes 1977). The early end of this range, however, is not well dated. Dogoszhi style rapidly increased in frequency and geographic distribution in the AD 1000s. Ceramic types characterized by Dogoszhi-style designs proliferated throughout the Chaco World between AD 980 and 1040 across four additional wares: Cibola White Ware, Tusayan White Ware, Tsegi Orange Ware, and Mesa Verde White Ware (see Table 1 for a list of Dogoszhi-style analogs). Dogoszhi style followed another region-wide style, called Black Mesa style (Figure 3; see Table 1 for analogs).

The evolution of Dogoszhi-style designs has been addressed by a number of researchers (Hayes and Lancaster 1975; Roberts 1927; Toll and McKenna 1997). Toll and McKenna (1997) note that the squiggle-line hachure generally precedes straight-line hachure, but it may also be found later. Squiggle hachure design elements first appeared around AD 880 as small components of the earlier Black Mesa style (e.g., Figure 3a), although it was just one of a variety of design elements in the Black Mesa-style design repertoire. Squiggle hachure was especially common on the analog type of Red Mesa Black-on-white (Figure 3b). These squiggle hachure elements changed over time, eventually being executed as the oblique and densely packed straight lines most characteristic of Dogoszhi-style designs (Figure 4; Hayes and Lancaster 1975:130).

Although there is a clear temporal progression of hachure elements, in some sequences, there is significant overlap in the production of Black 
Table 1. Analog Types Used in the Current Study.

\begin{tabular}{|c|c|c|c|c|}
\hline \multicolumn{5}{|c|}{ Dogoszhi-Style Analogs } \\
\hline Ware & Type & $\begin{array}{l}\text { Begin Date } \\
\text { (AD) }\end{array}$ & $\begin{array}{l}\text { End Date } \\
\text { (AD) }\end{array}$ & Short Reference \\
\hline Chuska White Ware & Brimhall Black-on-white & 1040 & 1150 & $\begin{array}{l}\text { Thomas C. Windes, personal } \\
\text { communication } 2015\end{array}$ \\
\hline Chuska White Ware & Chuska Black-on-white & 1040 & 1125 & $\begin{array}{l}\text { Thomas C. Windes, personal } \\
\text { communication } 2015\end{array}$ \\
\hline Cibola White Ware & Chaco Black-on-white & 1075 & 1150 & $\begin{array}{l}\text { Goetze and Mills 1993; } \\
\text { Toll and McKenna 1997; } \\
\text { Windes } 1977\end{array}$ \\
\hline Cibola White Ware & Gallup Black-on-white & 1040 & 1150 & Toll and McKenna 1997 \\
\hline Little Colorado White Ware & Padre Black-on-white & 1100 & 1250 & $\begin{array}{l}\text { Goetze and Mills 1993; } \\
\text { Hays-Gilpin and } \\
\text { Van Hartesveldt } 1998\end{array}$ \\
\hline Mesa Verde White Ware & Mancos Black-on-white & 980 & 1180 & Ortman et al. 2005 \\
\hline Tsegi Orange Ware & Cameron Polychrome & 1040 & 1170 & Christenson 1994 \\
\hline Tsegi Orange Ware & Tusayan Black-on-red & 1045 & 1240 & Christenson 1994 \\
\hline Tusayan White Ware & Dogoszhi Black-on-white & 1040 & 1210 & Christenson 1994 \\
\hline \multicolumn{5}{|c|}{ Black Mesa-Style Analogs } \\
\hline Chuska White Ware & Naschitti Black-on-white & 900 & 1000 & Windes 1977 \\
\hline Chuska White Ware & Newcomb Black-on-white & 875 & 1000 & Windes 1977 \\
\hline Cibola White Ware & Red Mesa Black-on-white & 880 & 1040 & Toll and McKenna 1997 \\
\hline Little Colorado White Ware & Holbrook A Black-on-white & 1050 & 1150 & $\begin{array}{l}\text { Goetze and Mills 1993; } \\
\text { Hays-Gilpin and } \\
\text { Van Hartesveldt } 1998\end{array}$ \\
\hline Mesa Verde White Ware & Cortez Black-on-white & 880 & 1060 & Ortman et al. 2005 \\
\hline San Francisco Mt. Gray Ware & Deadmans Black-on-gray & 900 & 1100 & $\begin{array}{l}\text { Breternitz 1966; } \\
\text { Goetze and Mills } 1993\end{array}$ \\
\hline Tusayan White Ware & Black Mesa Black-on-white & 900 & 1100 & Christenson 1994 \\
\hline
\end{tabular}

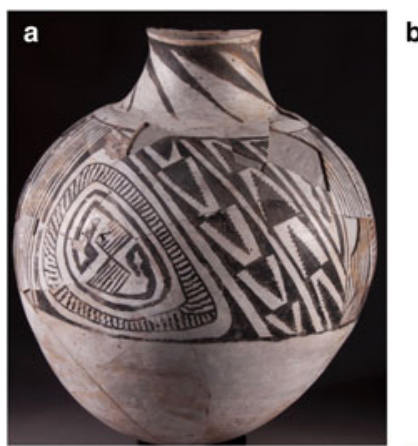

\section{b}

Figure 3. Examples of vessels of different wares decorated in Black Mesa style: (a) Black Mesa Black-on-white (height: $53.4 \mathrm{~cm}$, diameter: $42.0 \mathrm{~cm}$ ) (Collections of Grand Canyon National Park. Photo courtesy of American Southwest Virtual Museum [Northern Arizona University] and National Park Service); (b) Catalog \#18263, Red Mesa Black-on-white bowl, Site LA 2585, San Juan County, New Mexico (photo by Daisy Levine and Dennis Brandt. Removed from Navajo Nation Lands and administered by the Bureau of Indian Affairs, Museum Property Program at the Museum of Indian Arts \& Culture / Laboratory of Anthropology, Museum of New Mexico). (Color online) 


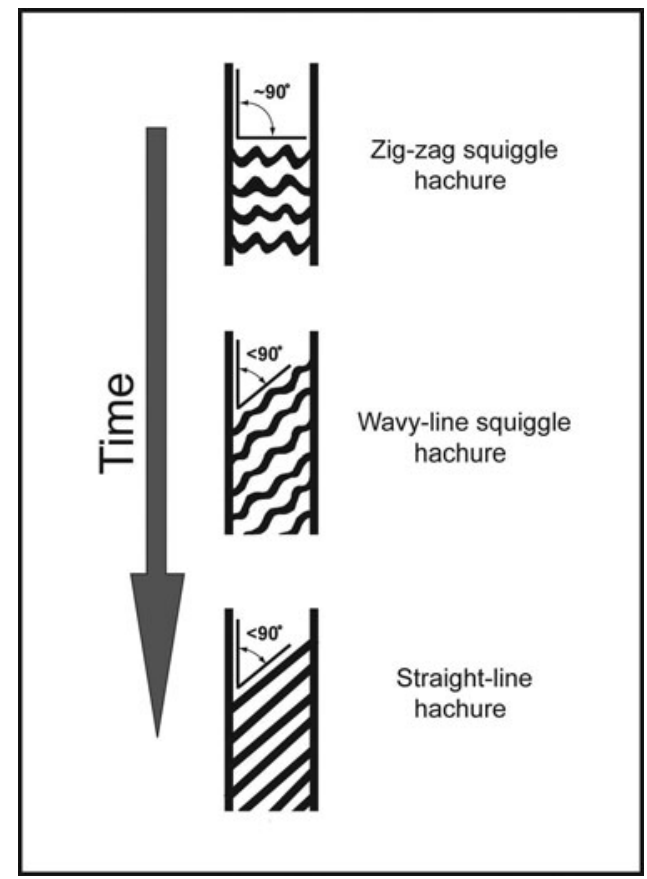

Figure 4. Chronological sequence of hachure execution for Dogoszhi-style ceramics, based on descriptions and photos of Cortez Black-on-white sherds in Hayes and Lancaster (1975:124, 130).

Mesa-style ceramics and those executed in Dogoszhi style. This is the case for Cortez Black-on-white in the Mesa Verde White Ware sequence (Hayes and Lancaster 1975:124), as well as for Black Mesa- and Dogoszhi-style analogs in the Chuska White Ware, Little Colorado White Ware, San Juan Red Ware (Allison 2008:Figure 2k-1), and Tusayan White Ware sequences. By contrast, there are no Black Mesa analogs in the Tsegi Orange Ware tradition that began production around AD 1000, coincident with a decline in the production of San Juan Red Ware (Allison 2008:24). Replacement also occurred in the Cibola White Ware sequence, with production of the Black Mesastyle analog in that sequence (Red Mesa Black-on-white) ceasing around AD 1040, when the Dogoszhi-style analog (Gallup Black-on-white) began being produced.

Regardless of the exact relationship between Black Mesa- and Dogoszhi-style analogs in a particular sequence, the early eleventh century marks a significant shift in ceramic production from earlier styles to a new suite of designs across the northern Southwest. This transition is closely associated with the most prolific material and ideological expansion of the Chaco World in the AD 1000s. Because of the presumed social significance of this shift in ceramic designs, our analysis evaluates the distribution of not only Dogoszhi-style ceramics but also Black Mesa-style ceramics, from which the hachure fill of Dogoszhi style likely derived.

The social importance of Dogoszhi style is further suggested by detailed analyses of the style's execution and the contexts in which the style occurs. Counter-change is produced when the area filled by the hachure (or solid fill in other design systems) is the same size as the unfilled area in between. The counter-change produced through balanced hachure and nonhachure designs is also found on other mediaincluding wood, textiles, ground stone, and rock art-in the Chaco area. In many of these cross-media cases, the counter-change is not executed with hachure but instead with contrasting colors, including red, yellow, or blue (see Bellorado 2020:Figures 4.2-E-F and 4.3-A-C). Bellorado (2020:4.1-B-C) documented the similarity between hachure filled designs and their layouts on Chaco Black-on-white cylinder jars and the raised tread designs on twined sandals made during the Chaco era from Pueblo Bonito and Aztec West. Plog (2003) has argued that the black-painted hachure on ceramics is a metaphor for turquoise and other blue-green colors used on these other objects. Given the importance of blue-green in counter-change designs on ceremonial objects, hachure may have had symbolic value to potters. Several scholars (Bellorado 2020; DeBoer 1991; Hays-Gilpin 1998; Hegmon et al. 2021) have argued that styles that occur pervasively on multiple classes of media are often charged with meaning, and these meanings often relate to important aspects of shared worldviews and ideological systems. The widespread use of Dogoszhi style on cylinder jars reinforces its potential significance (e.g., Crown and Wills 2003), but it was also used on a large number of other forms in daily use-such as serving bowls, pitchers, and jars. Hachure designs may even have symbolic significance in ceramic traditions outside the Chaco World (Russell et al. 2017). The sudden 
proliferation of Dogoszhi-style ceramics coinciding with major growth of other material indicators of the Chaco World and the potential symbolic importance of hachure designs on ceramic vessels are potential evidence favoring arguments for Dogoszhi as an elite style. In this study, we evaluate the distribution of Dogoszhi-style ceramics across the Chacoan World and what this distribution means for the possible social significance of the style and its development from earlier design repertoires.

\section{Data and Methods}

As Neitzel (1995:399) notes in her study of style and hierarchy in the Chaco World, "The major obstacle to testing expectations about stylistic patterning within the Chacoan regional system is the incompleteness of the available data." The development of the Chaco Social Networks (CSN) database is one step toward overcoming this obstacle, allowing for a larger-scale exploration of the distribution of both Dogoszhi-style and Black Mesa-style ceramics. The CSN database contains information about location, site size, and monumental and public architecture attributes for 467 Chacoan sites dating between AD 800 and 1300, with ceramic assemblages available for 298 of those sites (Mills et al. 2018). The database includes only sites that have Chacoan architectural features: great houses, great kivas, or both. Ceramic assemblages for each site have been previously apportioned across 10 50-year intervals, between AD 800 and 1300, using methods originally established for the Southwest Social Networks Project (Roberts et al. 2012).

For this analysis, the percentage of Black Mesa-style and Dogoszhi-style ceramics within the decorated assemblage was calculated for each great house or great kiva site in each 50 -year interval using the list of analog styles in Table 1. An important caveat to this list of Dogoszhi-style analogs is that most archaeologists in the Mesa Verde region have combined vessels with a variety of design repertories (including Dogoszhi style) into a single type based on their shared technological attributes: Mancos Black-on-white (Breternitz et al. 1974). As such, only a subset of Mancos
Black-on-white is decorated with all-over hachure designs. ${ }^{2}$ However, for 19 assemblages where analysts recorded the style of individual Mancos Black-on-white sherds, Dogoszhi-style sherds comprised, on average, $40 \%$ of the Mancos Black-on-white sherds (see Table 2). The relative frequency of Dogoszhi-style Mancos Black-on-white sherds seems to have a rough correlation with distance from Chaco Canyon and the San Juan Basin, with lower proportions of Dogoszhi-style sherds in assemblages from southeast Utah and the Mesa Verde region. So as not to overrepresent the relative frequency of Dogoszhi-style ceramics in assemblages dominated by Mancos Black-on-white, we counted only $40 \%$ of Mancos Black-on-white sherds as analogous in our analysis. This approach does not account for variability between sites, but it does more accurately capture the distribution of Dogoszhi style than the alternatives of excluding all Mancos Black-on-white sherds, or using $100 \%$ of those sherds.

The relative frequency of both Black Mesaand Dogoszhi-style ceramics was also calculated for every site within eight Chacoan great house communities included in the CSN database (Supplemental Table 1). Chacoan communities consist of a number of small residential sites that are associated with one or more great houses and/or great kivas (Doyel et al. 1984). Some communities have more than one associated great house or great kiva, whereas others have only one of these features. For Chacoan outlier communities, Black Mesa- and Dogoszhi-style frequency was averaged for each interval, independently for small sites and for sites with Chacoan architecture.

To evaluate the distribution of each style across the Chaco World, the proportion of each style was compared against other site-level metrics for each 50-year interval. These site-level metrics serve as proxies for the possible importance of a site in the Chacoan settlement system and include size class of the site, number of rooms, and eigenvector centrality. A size class was assigned to each site based on the four size classes identified previously by Jill Neitzel (1995:399) as potential tiers of a settlement hierarchy. Mean room counts constitute another proxy for each site's importance, but they are 
Table 2. Proportion of Mancos Black-on-White with Dogoszhi-Style Decoration.

\begin{tabular}{|c|c|c|c|c|c|}
\hline Site & Region & $\begin{array}{c}\text { Mancos } \\
\text { Black-on-White } \\
\text { \# of Sherds }\end{array}$ & $\begin{array}{l}\text { Dogoszhi } \\
\text { Style } \\
\text { \# of Sherds }\end{array}$ & $\begin{array}{c}\text { Proportion } \\
\text { (of Decorated } \\
\text { Assemblages) }\end{array}$ & Source \\
\hline 5MT5498 & Mesa Verde / McElmo & 425 & 156 & 0.37 & Rohman 2000:5-6 \\
\hline $\begin{array}{r}\text { Badger House } \\
\text { Community }\end{array}$ & Mesa Verde / McElmo & 8,864 & 1,861 & 0.21 & $\begin{array}{l}\text { Hayes and Lancaster 1975: } \\
\text { Table } 32 \text { (straight } \\
\text { hachure) }\end{array}$ \\
\hline Aztec AMNH 03 & Middle San Juan & 71 & 27 & 0.38 & Reed 2005 \\
\hline Aztec WACC 06 & Middle San Juan & 198 & 126 & 0.64 & Reed 2007 \\
\hline Hilltop & Middle San Juan & 200 & 80 & 0.40 & Reed 2005 \\
\hline $\begin{array}{l}\text { Holmes Group, } \\
\text { Excavation }\end{array}$ & Middle San Juan & 34 & 29 & 0.85 & Reed 2005 \\
\hline Holmes Group, Survey & Middle San Juan & 40 & 13 & 0.33 & Reed 2005 \\
\hline Jaquez & Middle San Juan & 229 & 111 & 0.48 & Reed 2005 \\
\hline Mine Canyon & Middle San Juan & 146 & 80 & 0.55 & Reed 2005 \\
\hline Morris 39 & Middle San Juan & 85 & 27 & 0.32 & Reed 2005 \\
\hline Morris 41 & Middle San Juan & 150 & 58 & 0.39 & Reed 2005 \\
\hline Salmon, Sample & Middle San Juan & 387 & 122 & 0.32 & $\begin{array}{l}\text { Reed 2006; Reed and } \\
\text { Myers } 2006\end{array}$ \\
\hline $\begin{array}{l}\text { Salmon, All } \\
\text { Occupations }\end{array}$ & Middle San Juan & 5,714 & 1,227 & 0.21 & Franklin 2006:Table 21.2 \\
\hline Salmon, Survey Data & Middle San Juan & 51 & 26 & 0.51 & Reed 2005 \\
\hline Tommy Site Midden & Middle San Juan & 89 & 55 & 0.62 & Reed and Goff 2000 \\
\hline Tommy Site, All & Middle San Juan & 468 & 222 & 0.47 & Reed 2008 \\
\hline Edge of the Cedars & SE Utah & 120 & 12 & 0.10 & Harris 2014:Appendix A \\
\hline Cottonwood Falls & SE Utah & 54 & 12 & 0.22 & Harris 2014:Appendix B \\
\hline \multirow[t]{4}{*}{ Three Kiva Pueblo } & SE Utah & 273 & 78 & 0.29 & Harris 2014:Appendix C \\
\hline & Mean & & & 0.40 & \\
\hline & Standard Deviation & & & 0.19 & \\
\hline & Median & & & 0.39 & \\
\hline
\end{tabular}

not available for all sites in the CSN database due to variability in site recording. Furthermore, site size is invariant across all intervals examined here; without detailed intrasite information, it is difficult to vary size with the actual growth of a site. As such, our measure of mean site size will tend to overestimate true site size for longlived sites and for early intervals in the occupation of a site.

As a final proxy measure of a site's importance, we used network measures from previously published studies to evaluate the proportion of Black Mesa- and Dogoszhi-style in relation to the position of a given site in the overall network of ceramic similarity. The construction of networks used here is described in detail by Mills and colleagues (2018). The networks constructed for this prior project are weighted networks where the similarity of the ceramic assemblage between every pair of sites per 50-year interval is seen as an estimate of the probability that those two sites were connected (further suggesting some degree of interaction). The present research makes use of a particular network metric-eigenvector centrality-calculated for use in this prior work (Mills et al. 2018). In network analysis, centrality is viewed as a measure of the social influence and importance of an actor, which in this case is the settlement. Eigenvector centrality considers not only a node's immediate connections but also that node's higher-order connections weighted inversely to the degree of separation to the target node (Newman 2010), providing a good measure of the importance of a node (site) in the overall structure of the network.

Style prevalence was also evaluated on a region-by-region basis using macroregional groupings encoded in the Chaco Social Networks database. Measures of variance were calculated for macroregions to evaluate the homogeneity of Black Mesa- and Dogoszhi- 
style ceramic distributions within these regions (Supplemental Tables 2 and 3). Both interquartile range and standard deviation were calculated, but only for regions with a $\geq 10 \%$ average percentage of Black Mesa- or Dogoszhi-style ceramics and with $\geq 8$ sites in the region. As the number of sites in a region or the mean percentage of either style in a region approaches 0 , measures of variability become both increasingly unnecessary to interpret the distribution of ceramics and less informative about that distribution.

\section{Analysis Results}

\section{Relationship of Style Frequency and Site Size and Centrality}

The percentages of Dogoszhi style by different measures of site size show that there is a high degree of variation among our sample of great house and great kiva sites. Looking first at the size classes defined by Neitzel (1995; Figure 5), "Small" and "Medium" sites have values that range from $0 \%$ to $91 \%$ and $0 \%$ to $71 \%$, respectively. Four of the five sites in the "Large" and "Very Large" categories, however, have higher than mean frequencies of Dogoszhi style (though perhaps not exceptionally high), as expected for an elite style. The lower ratio for Aztec may be a product of the later occupation of the site, which is often considered the twelfth-century replacement for Pueblo Bonito in terms of importance within the Chaco World. Both Chetro Ketl and Pueblo del Arroyo are a stone's throw from Pueblo Bonito and part of the dense cluster of sites in Chaco Canyon often referred to as "Downtown Chaco."

Figures 6 and 7 show the relationship between both Black Mesa- and Dogoszhi-style through time compared to site size (number of rooms) and network (eigenvector) centrality through time. Rank-order Spearman's $\rho$ correlation coefficients are reported. There is little correlation between site size or eigenvector centrality and Dogoszhi-style proportions, which illustrates a high degree of variation and no clear associations. There is a stronger rank-order correlation between Black Mesa-style and eigenvector centrality, increasing from the AD 900-950 to the 950-1000 interval, although there is still considerable variability. The correlation, however, between the relative frequency of Black Mesastyle ceramics and site size is near 0 . This indicates that if either of these styles is associated with network prominence, it is this earlier style rather than Dogoszhi style. Because our site size estimates are invariant over time, however, the earlier style correlations may be inflated.

\section{Relationship of Style Frequency at Great Houses and Great Kivas by Macroregion}

All evaluated metrics indicate a high degree of variability in the spatial distribution of Black Mesa- and Dogoszhi-style ceramics by subareas of the Chaco World (Figures 8 and 9). During the peak of Dogoszhi-style production, in the intervals AD $1050-1100$ and $1150-1200$, variability is high across the entire Chaco World and within macroregions (Supplemental Table 2). Mean proportion of Dogoszhi-style ceramics varies highly among regions, between 0.01 and 0.60 in the intervals of peak production. Standard deviations are likewise high for both intervals. It is apparent from examining these measures of variability that although some regions have a low or zero frequency of Dogoszhi-style ceramics, among regions with higher frequencies of the style, there are no regions without considerable variability. This pattern follows even for the highest frequency regions, such as the Chuska Slope and Lobo Mesa / Red Mesa Valley. Notably, of the macroregions with a higher mean proportion of Dogoszhi style, Chaco Canyon has by far the least variability for both intervals of peak production.

Variability is similarly high in the distribution of Black Mesa-style ceramics, with slight differences. The mean proportion of Black Mesa-style ceramics during the peak of Black Mesa production (the AD 900-950 and 950-1000 intervals) is higher across all regions (Supplemental Table 2) than the mean frequency of Dogoszhi-style ceramics during the peak of its production (Supplemental Table 3). Standard deviations in periods of peak production for both styles are generally comparable when considering both all regions together and regions individually.

Variability within and among regions is visible spatially in distributional heat maps of Black Mesa-style ceramics in the interval of AD 950 to 1000 and Dogoszhi-style ceramics 




${ }^{\star}$ Only sites with Great House and/or Great Kiva architecture.

\section{Room Size Class}

Figure 5. Boxplots of Dogoszhi-style relative frequencies by Neitzel's (1995) site size classes for Chacoan great houses.

in the interval AD 1050 to 1100 (Figure 10). The map of the distribution of Dogoszhi-style ceramics is mostly circumscribed by the bounds of the San Juan Basin, in the core of the Chaco World, with a few exceptions. It is also apparent, however, that Dogoszhi-style ceramics are distributed highly variably within these geographic limits. Although larger areas of generally high or low frequency are apparent, the frequency gradient within these areas is irregular and marked by lower-frequency sites within otherwise highfrequency areas.
Relative to the distribution of Dogoszhi-style ceramics, Black Mesa-style ceramics are more homogenously distributed within the regions where the style occurs frequently. In general, the distribution of Black Mesa-style spatially follows a more even gradient than the more irregular distribution of Dogoszhi style.

Finally, it is important to note that the macroregions with the highest percentage of Black Mesa-style in the AD 900-950 and 950-1000 intervals are generally among the regions with the highest percentage of Dogoszhi style in the 

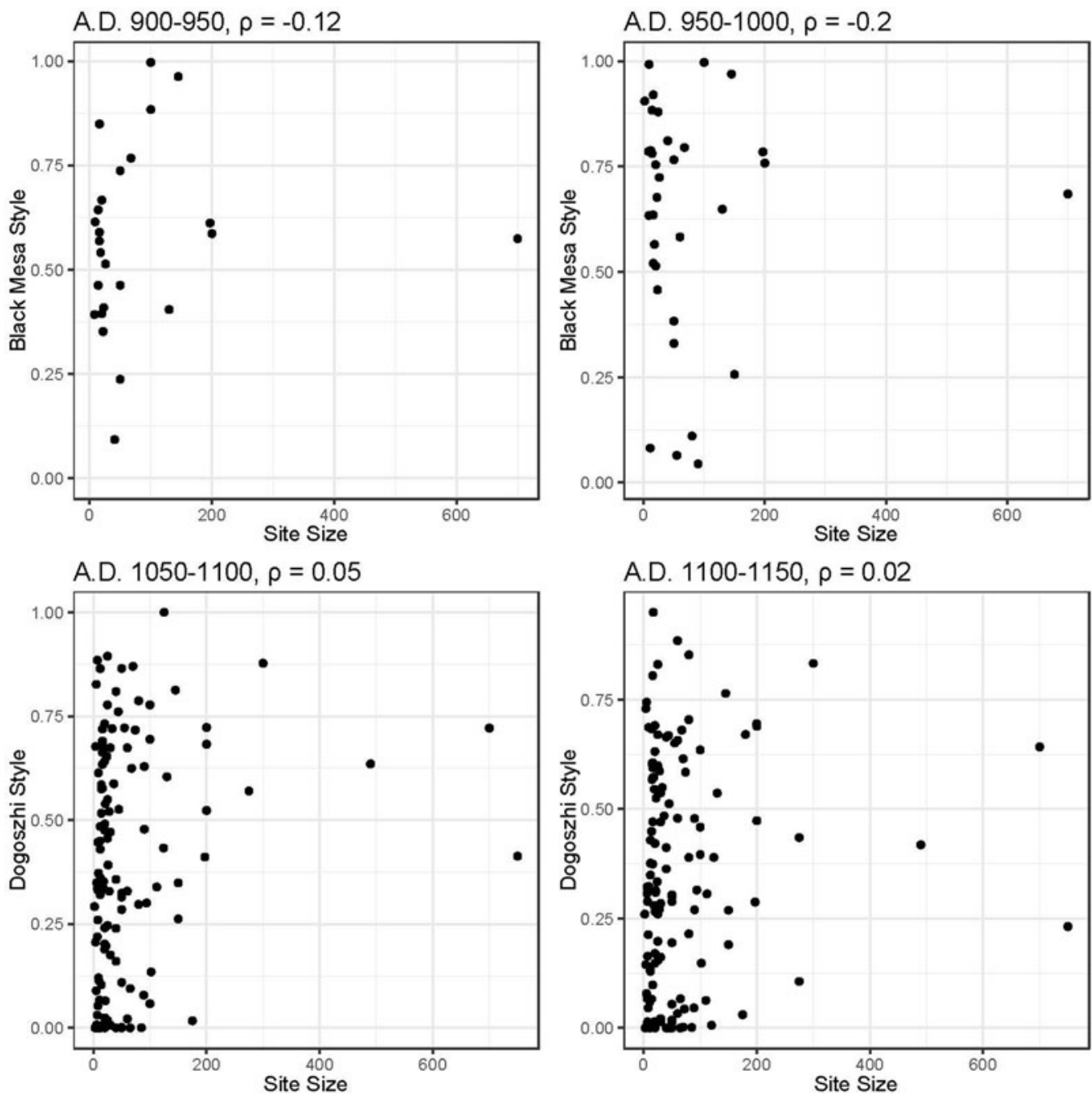

Figure 6. Relationship of site size with Black Mesa- and Dogoszhi-style relative frequency for intervals of peak production. Pearson's $r$ correlation coefficient noted for each interval.

AD 1050-1100 and AD 1100-1150 intervals. We find that there is a positive rank-order correlation $(\rho=0.56)$ between mean proportion of Black Mesa-style ceramics at a site during the AD 950-1000 interval and the mean proportion of Dogoszhi-style ceramics at the same site in the AD 1050-1100 interval. In particular, the Chuska Slope, Lobo Mesa, Middle San Juan, and Chaco Canyon regions are among the regions with the highest values for both styles. The most prominent exception to this pattern is the Rio Puerco of the West macroregion. Although Black Mesa-style ceramics are common in this region between $\mathrm{AD} 900$ and 1000 (between $48 \%$ and $68 \%$ of decorated assemblages, on average), the mean percent of Dogoszhi-style ceramics in this region between AD 1050 and $1150(21 \%-27 \%)$ is slightly below the mean for sites as a whole and well below the aforementioned regions with high proportions of both styles. This observation is further validation of the pattern previously noted by Windes (1984) of a sharp decline in Dogoszhi-style ceramics at the southern edge of the San Juan Basin, where Puerco and Reserve styles predominate instead. 

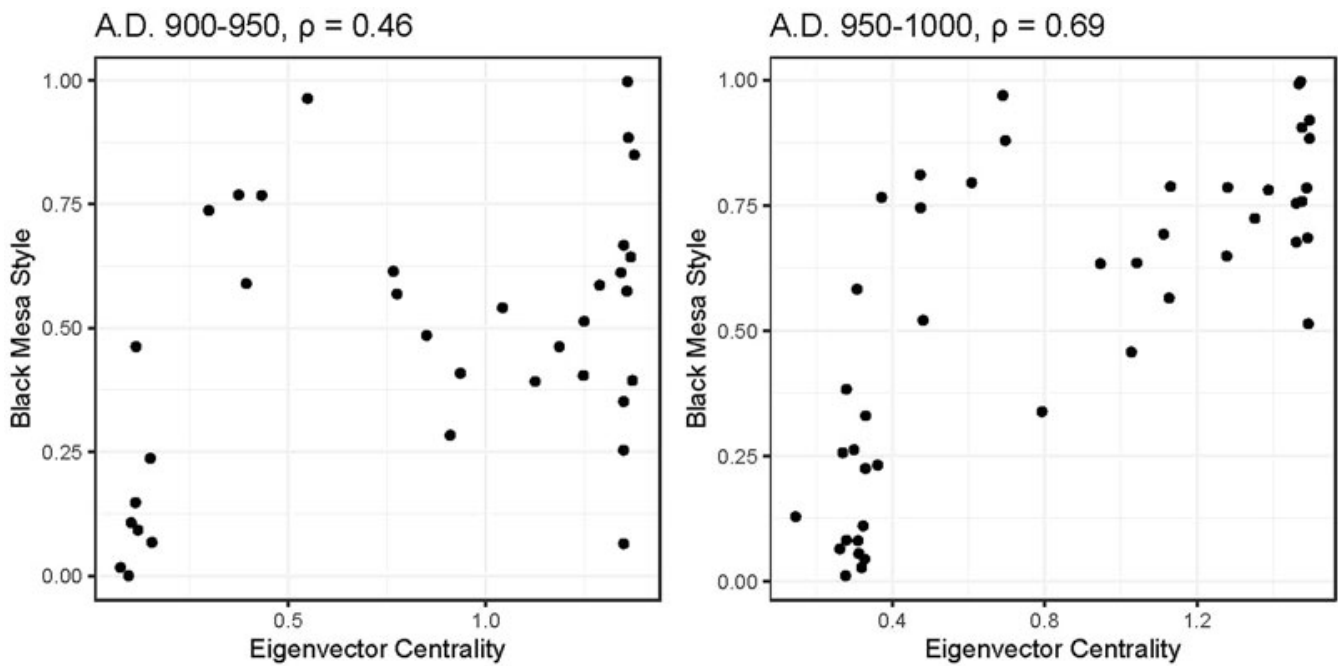

A.D. $1050-1100, \rho=0.08$
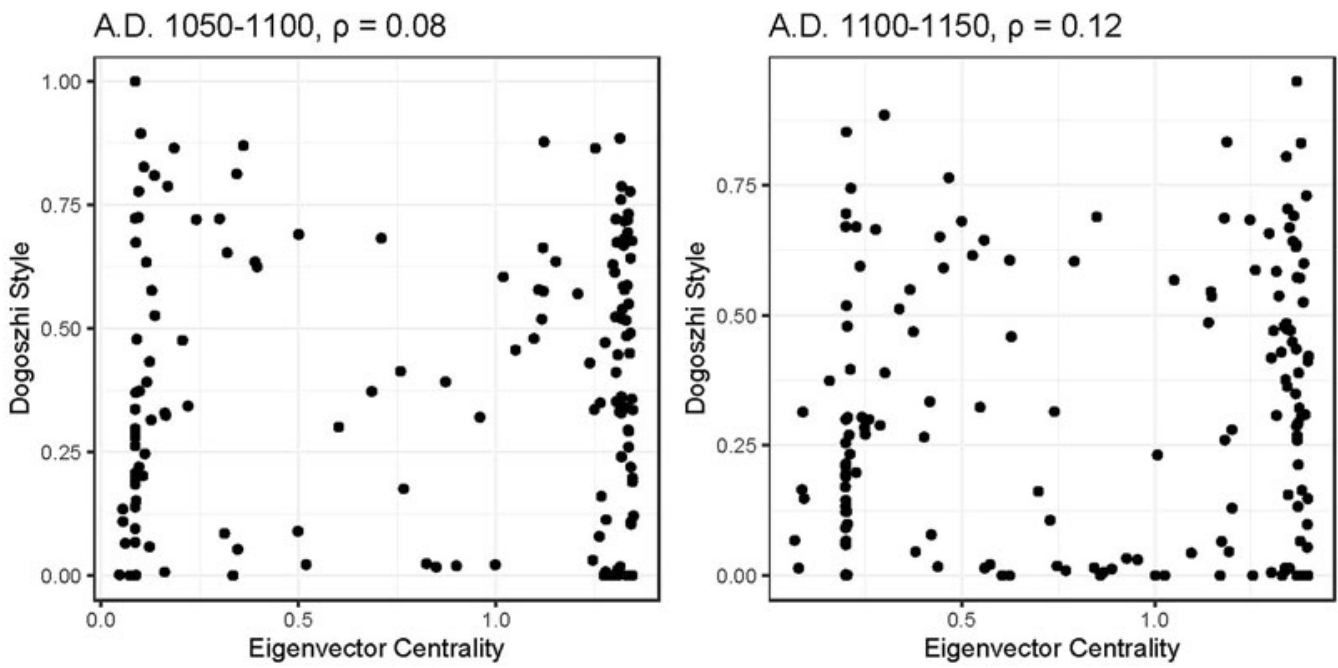

Figure 7. Relationship of eigenvector centrality with Black Mesa- and Dogoszhi-style relative frequency for intervals of peak production. Pearson's $r$ correlation coefficient noted for each interval.

\section{Relationship of Style by Great House versus} Small Houses within Chaco Communities

In contrast to the high variability within and between regions, our distributional analysis of both Black Mesa- and Dogoszhi-style ceramics within great house and great kiva outlier communities indicates a high degree of similarity between smaller residential sites and large sites featuring Chacoan public architecture. Table 3 summarizes Black Mesa- and Dogoszhi-style percentages in the eight communities tested. The similar frequency of styles at both small and large house sites is true across all intervals and for communities with varying mean percentages of each style. For instance, sites in the Kin Nizhoni community-both large and smallhave a high frequency of both Black Mesaand Dogoszhi-style ceramics, between $80 \%$ and $100 \%$ during intervals of peak production, whereas both large and small sites in the Chacra Mesa community have more average frequencies of these styles. For the instances where this generalization is not true-namely, that the relative frequency of a style is not the same at the small and large sites in a community - the small sites tend to have the higher proportion of a style. 


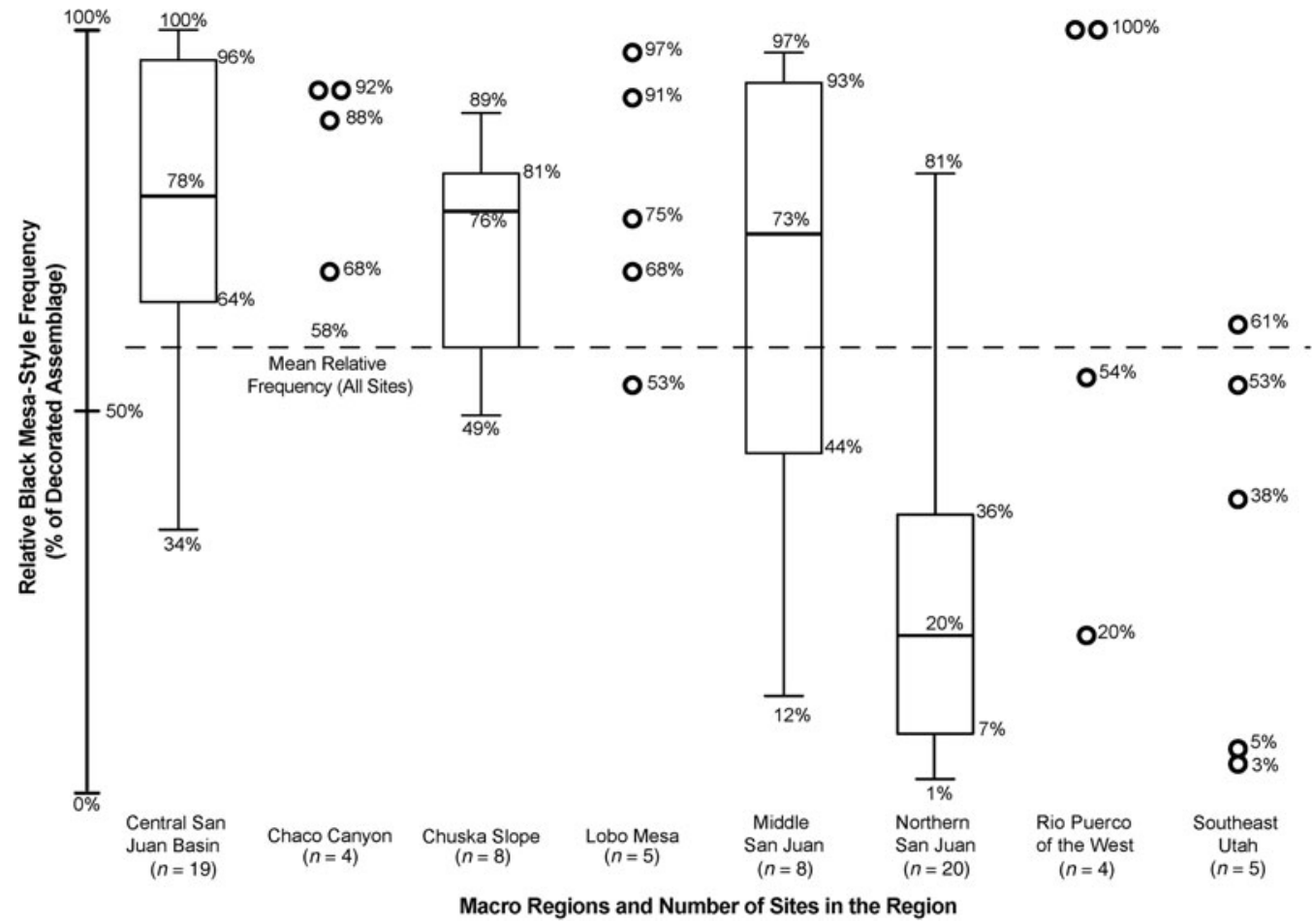

Figure 8. Boxplots of Black Mesa style by region (AD 950-1000), where number of sites is greater than seven and percentage is greater than $10 \%$.

A related observation is that within the eight Chacoan communities analyzed in this study, the sites with large, public architecture are never the sites with the highest percentages of either Black Mesa or Dogoszhi style. These observations match our observations on the regional distribution of these styles, where the highest frequencies of Dogoszhi-style ceramics are in assemblages from small sites (see Figure 5). The pattern we find within Chacoan outlier communities, however, also contrasts somewhat with the pattern we observe at the regional scale, in that the largest great houses ("Large" and "Very Large" sites) have higher-than-average frequencies of Dogoszhi-style ceramics.

\section{Conclusions}

\section{Dogoszhi as a Marker of Regional Community Membership}

On the basis of this analysis, we find only partial evidence supporting the proposition that Dogoszhi-style ceramics may have acted as markers of regional-scale community identity in the same way or at the same scale as Chacoan architectural features. The distribution of Chacoan architecture is more widespread, with ceramic styles other than Dogoszhi predominating in the northern and southern portions of the Chaco World. Furthermore, even within the core of the Chaco World (the middle San Juan Basin and surroundings), there is considerable variation in the distribution of Dogoszhi-style ceramics. As discussed, the distribution of a style used to mark community membership and social boundaries should be relatively homogenous within the community it marks, whereas the boundaries of its distribution should be relatively sharp (Hegmon et al. 2021; Neitzel 1995:397; Plog 1995:372). Our analysis indicates that the percentage of Dogoszhi-style ceramics in an assemblage drops rapidly beyond the core regions of the Chaco World within the San Juan Basin. Sharp boundaries also exist within this primary extent, however. Even in regions with a high average percentage of Dogoszhi-style ceramics, such as 


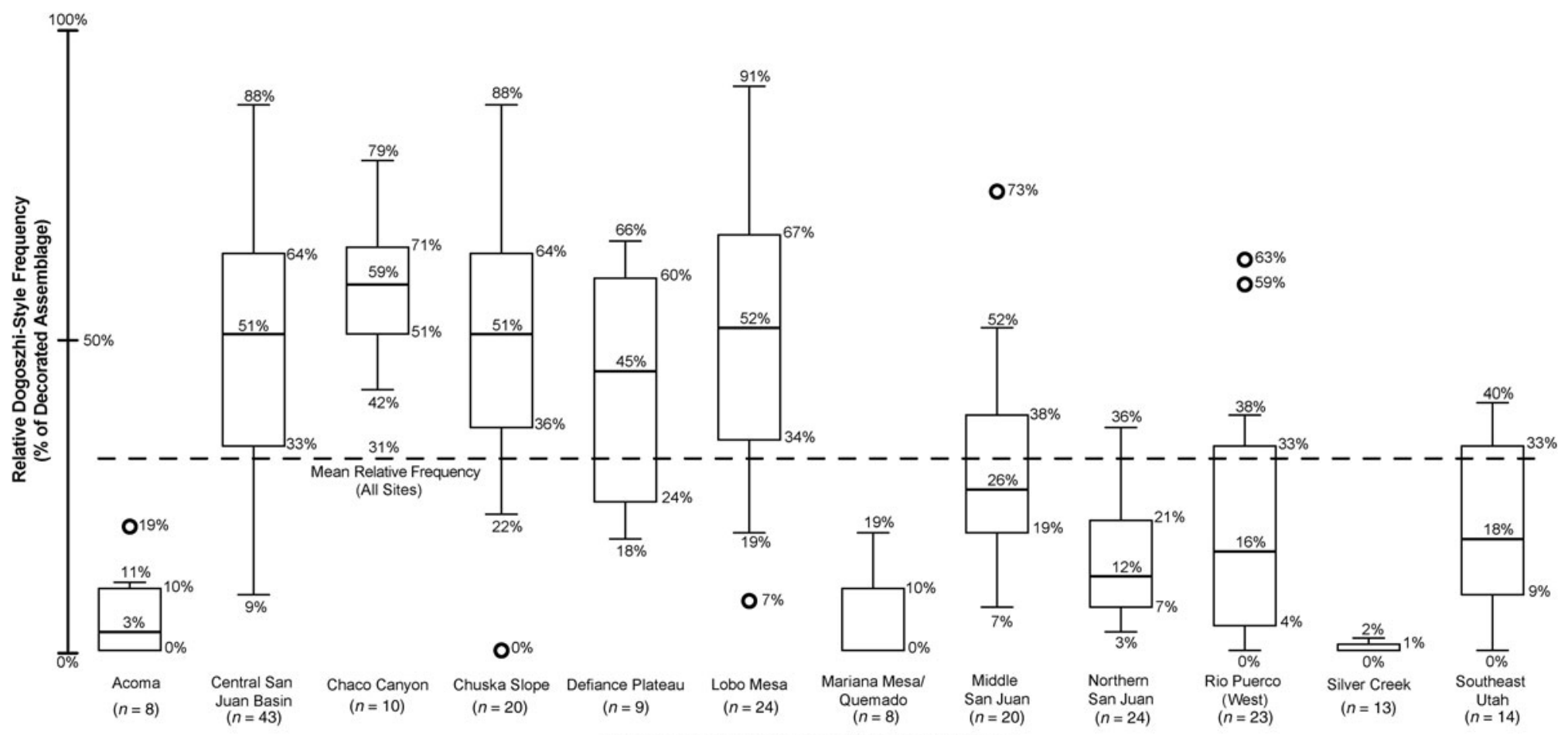

Figure 9. Boxplots of Dogoszhi style by region (AD 1050-1100), where number of sites is greater than seven and percentage is greater than $10 \%$. 

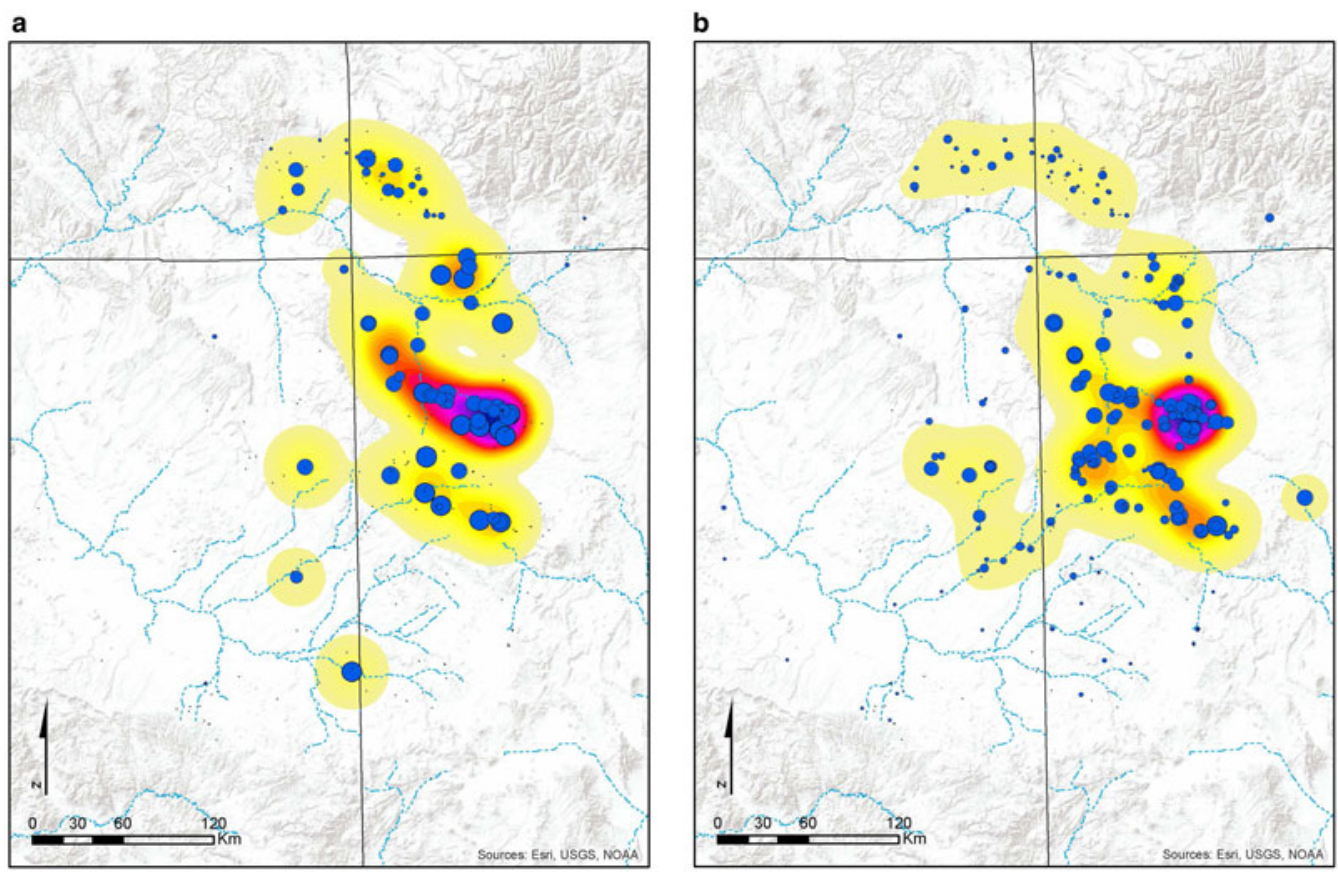

Figure 10. Inverse Distance Weighted (IDW) heat map of (left) Black Mesa-style relative frequencies (AD 950-1000) and (right) Dogoszhi-style relative frequencies (AD 1050-1100). (Color online)

the Chuska Slope, some sites have more than twice the percentage of the style than neighboring sites (see Figure 9). Although this sharp drop in Dogoszhi-style frequency beyond the San Juan Basin matches our second expectation for a style marking community membership, the highly variable distribution of the style within this geographic extent does not match our first expectation of homogeneity within the proposed community of the core Chaco World.

On this basis, we can draw two conclusions about Dogoszhi style as a marker of membership in the Chaco World. First, because ceramics decorated in this style are limited largely to the core of the Chaco World in the San Juan Basin, with some exceptions such as the Defiance Plateau macroregion, the style does not likely mark participation in the Chaco World as a whole (as suggested by Toll et al. 1992). Instead, it marks participation in a community that is either coterminous with the core regions of the Chaco World or that is contained within these regions. The highly discontinuous distribution of the style within its maximal geographic extent supports the latter conclusion. This conclusion is further supported by our observation that Dogoszhi-style ceramics are distributed highly homogenously within the eight Chacoan communities we analyzed. This indicates that, at the level of individual communities, Dogoszhi style likely acted as a marker of membership, even if it did not function this way at the scale of the macroregions identified in the CSN database.

\section{Dogoszhi as Elite Style}

We also find little evidence in the distribution of Dogoszhi-style ceramics to support the proposition that Dogoszhi acted as an exclusively elite style throughout the Chaco World, primarily because of its presence in large quantities at small sites and medium sites. We do find, however, that the very largest of great houses (those with room counts above 250 rooms), generally had much higher proportions of Dogoszhi style than the population on the whole (see Figure 5). This fits one of our expectations of an elite style-of differential distribution across a settlement hierarchyalthough similar proportions of Dogoszhi style at some smaller sites means there is no 


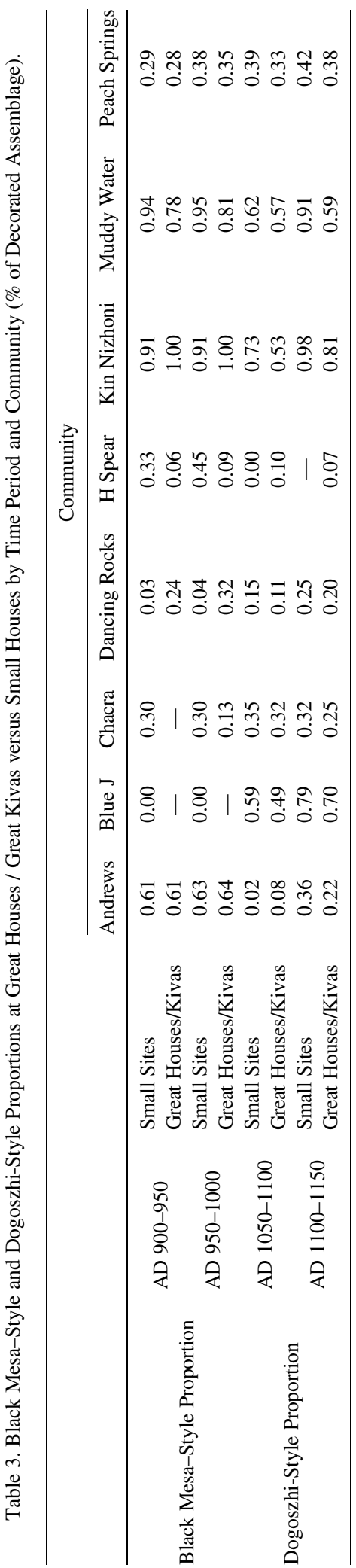

one-to-one correlation of site importance and proportion of Dogoszhi-style ceramics.

From these observations we draw several conclusions about Dogoszhi as an elite style in the Chaco World. First, the near-zero correlation of both centrality and site size with Dogoszhi-style percentage violates the expectation of elite styles as more frequent at elite settlements. The relationship to site size is particularly contrary to the expectation given that, even though the largest sites uniformly have high proportions of Dogoszhi-style ceramics, the largest sites do not have a higher proportion of the style than the highest proportion among smaller sites. These smaller sites are likely to have been shorter lived than Chaco great houses, which may have more mixed deposits and/or were places that housed a greater diversity of people. The high percentages at small sites in certain areas support the idea that for some subregions, Dogoszhi style marked broader community membership as opposed to elite versus nonelite social groups. Second, the low variability in the proportion of both Black Mesa- and Dogoszhi-style ceramics within Chaco Canyon-at least compared to other regions with high mean proportions of each style (see Figures 8 and 9)-indicates that Dogoszhi-style ceramics were consistently important to or consumed by Canyon elites, even if they were not the only major consumers of the style. Third, the conflicting interpretation of the first two points (of both widespread distribution of the style and elite preference for the style) demonstrates that Dogoszhi-style ceramics had multiple values within the Chaco World, depending in part on the context of consumption. Although Dogoszhi-style ceramics are not uniformly more frequent at larger sites (i.e., those that are higher in the settlement hierarchy, as we might expect for an elite style), there are intrasite contexts in which the style may be concentrated. For example, the clustering of cylinder jars in Room 28 at Pueblo Bonito, of which more than $75 \%$ are decorated in Dogoszhi style (Crown 2018), suggests that it did serve as a marker of elite status for at least some social elements within a few great houses and for vessels used in restricted contexts, even if it did not serve this function across the Chaco World as a whole. 


\section{The Social Value of Dogoszhi Style}

On the basis of these conclusions, we can make three inferences about the social value of Dogoszhi-style ceramics within the Chaco World. First, although a primary marker of an elite style is its greater occurrence in elite contexts, elite styles should also reach their greatest elaboration in the most important, central, or restricted elite contexts (Neitzel 1995:397). Given this, we suggest that Chacoan elites may have marked their special social status not through simply accessing and consuming Dogoszhi-style ceramics, but rather through special contexts of use (like the aforementioned cylinder jar cache at Pueblo Bonito) or through special forms or executions of Dogoszhi-style ceramics (again, like the aforementioned cylinder jars). Our analysis would not capture these distinctions within the style, potentially resulting in our somewhat contradictory findings.

Second, Dogoszhi-style ceramics may have held multiple values across distinct social contexts that could be the result of heterarchical structures of power and status within the Chaco World. Such a heterarchical structure would have complemented the hierarchical structure evident within Chaco Canyon and its successor in the Middle San Juan-the Aztec Complexand similar structures between these areas and other great house communities. In a heterarchical social structure, social elements are either unranked or can be ranked in multiple ways (Crumley 1995:3). In such a structure, social power and prestige can be counterpoised, rather than ranked, so that power and prestige are generated from a diversity of sources. This structure has been previously argued as applying to Western Pueblo societies in the Pueblo IV period of the Southwest (Rautman 1998; Saitta and McGuire 1998). Although Chaco was very different from the later Pueblo IV societieswhich have been interpreted as a reaction to the hierarchy of Chaco society (Fowles 2012) - if sources of social prestige in the Chaco World were diverse, we could expect that markers of prestige would be similarly diverse to distinguish not only elites from nonelites but elites of one kind from those of another kind. In this case, the high proportion of Dogoszhi-style ceramics at some, but not all, lower-ranked sites may reflect the diversity of sources of prestige within the Chaco World, particularly if those sources had geographic correlates. Distinct methods for signaling status may have been unified under a larger ideological system of Chacoan values. For instance, if Dogoszhi style is representative of the cosmologically significant color bluegreen, as has been previously argued (Plog 2003), Dogoszhi style may have been one component in a larger symbolic and stylistic system of Chacoan value placed on the color blue-green. Some segments of the Chacoan elite population may therefore have referenced this broader system of Chacoan values through intensive consumption of Dogoszhi-style ceramics, whereas other elites may have eschewed Dogoszhi-style ceramics in favor of other referents of possible pan-Chacoan values. The fact that the largest of Chacoan sites almost all have significant proportions of Dogoszhi-style ceramics may reflect the presence of multiple groups of elites at these sites, whereas the greater variability in Dogoszhi-style consumption at smaller sites may reflect their ability to host a smaller diversity of elites who draw legitimacy from only some sources.

Third, the irregular geographic distribution of communities with high frequencies of Dogoszhi-style ceramics is potentially explained through a growth of associations, sodalities, or other similar organizations in response to the expansion of the Chaco World around AD 1000. Organizations such as sodalities can crosscut other social boundaries, serving an integrative function in situations of increased interaction across these boundaries (Ware 2014:35) or a competitive function when they are different factions (Plog and Solometo 1997). Likewise, broadly shared styles can serve a similar integrative function across distinct social boundaries (Hegmon 1995:41-43), but in other cases, a variety of styles may be expected in situations such as migration in what Hegmon and colleagues (2016) call "representational diversity." If the expansion of the Chaco World in the early eleventh century created a larger system of interaction within the greater San Juan Basin, sodalities and other cross-cutting social structures such as alliances built through intermarriage 
and cooperative building programs may have been increasingly necessary to maintain a system of cross-regional interactions. In this scenario, Dogoszhi-style ceramics may have been a stylistic marker of just one or a subset of these crosscutting associations within a system of representational diversity.

\section{Relationship with Black Mesa Style}

These inferences are strengthened by our comparison between the distribution of Black Mesa style with the distribution of Dogoszhi style. This comparison suggests that the social value of Dogoszhi style may have been related to specific geographic associations, particularly with the Chuska Slope and Lobo Mesa macroregions. A primary conclusion of our analysis of Black Mesa style is that the frequency of Black Mesa-style ceramics in a macroregion during peak intervals of production for that style (AD 900-1000) strongly predicts the frequency of Dogoszhi-style ceramics in that same region, with the important exceptions of the Rio Puerco of the West macroregions. Yet, the existence of these exceptions to a strong overall pattern suggests that the social value of Dogoszhi style is not exactly analogous with that of Black Mesa style. The transition to Dogoszhi style from the earlier Black Mesa style in the early eleventh century coincides with other major transformations in the structure of the Chaco World, particularly the rapid spread of hallmarks of the Chaco World, such as great-house architecture, across the Four Corners region. The high average proportions of Dogoszhi-style ceramics in assemblages from Chaco Canyon and the Middle San Juan - the core of the Chaco World-heighten this connection. The greater formality of Dogoszhi style relative to Black Mesa style also suggests a greater value placed on the production of Dogoszhi-style ceramics relative to their Black Mesa counterparts.

The continuity of Black Mesa- and Dogoszhi-style ceramic consumption in the core regions of the Chaco World around Chaco Canyon, as well as in the more outlying macroregions of the Chuska Slope and Lobo Mesa, is informative about both the origins of Dogoszhi as a style and its probable social value. This continuity in the popularity of both styles, combined with the earliest Dogoszhi-style analogs belonging to the Chuska White Ware series, suggests that the style may have originated in the late tenth- and early eleventh-century communities of the Chuska Slope and spread effectively to communities to the east in the San Juan Basin and to the south in the Lobo Mesa macroregion. The discontinuity of high Black Mesa-style consumption followed by low Dogoszhi-style consumption in the Rio Puerco of the West macroregion further suggests that communities in the Chuska Slope, Lobo Mesa, and Red Mesa regions were the primary agents in developing a style with distinct social value from the earlier and more widespread Black Mesa style.

Archaeologists have previously connected communities in the Chuska Slope with Chaco Canyon itself through importation of timbers for great house construction (Betancourt et al.1986; Guiterman et al. 2016), Narbona Pass chert (Cameron 2001), and large quantities of ceramics (Cameron and Toll 2001; Warren 1976). Importantly, recent research suggests that timber importation from the Chuska Mountains into Chaco Canyon was most prolific around AD 1000 (Guiterman et al. 2016), at the same time that communities in the Chuska Slope were likely developing early forms of Dogoszhi style. We therefore conclude that the social value of Dogoszhi-style ceramics may largely be tied to its geographic associations with the Chuska Mountains and/or the communities in the Chuska Slope. Furthermore, communities in Chaco Canyon preferentially imported timbers and Zuni Spotted Chert from the Zuni Mountains (Cameron 2001; Guiterman et al. 2016), in the vicinity of communities assigned to our Lobo Mesa macroregion. These connections between Chaco Canyon sites and regions of high Dogoszhi-style frequency underscore the social value Chacoan elites put on making connections with place.

We conclude that one of many sources of prestige and power in the Chaco World was based in developing strong connections to the region of the Chuska Mountains, and Dogoszhi style served as one marker, among many, of that place-based status. Furthermore, as we have already argued, the distribution of Dogoszhi-style ceramics was irregularly structured on the basis 
of cross-cutting social boundaries within the Chaco World. The association or associations marked by Dogoszhi-style ceramics may have originated among the same communities in the Chuska Slope that likely played a large role in developing Dogoszhi style as distinct from the tradition of Black Mesa-style ceramics. This viewpoint helps synthesize our observations that Dogoszhi style likely acted as a marker of both elite status and participation in a social group internal to the Chaco World. The social value of Dogoszhi-style ceramics in both cases may be based strongly on the association of the style with the Chuska Mountains and Lobo Mesa regions.

Our conclusions support the general interpretation that elites use style in multiple ways. One way is to differentiate themselves through the use of particular styles on objects of great value. At Chaco, examples of this are drinking vessels used in special contexts at Pueblo Bonito (Crown 2018) or particular forms of ornaments placed in burials and caches (Mattson 2016). Another way that elites may employ style is by encouraging nonelites to use the style to foster shared identities, build alliances, and promote cooperation (Schortman et al. 2001). Chaco Canyon elites may have intentionally adopted a popular region-wide style in order to build coalitions and encourage cooperation that would have been necessary for constructing great kivas and great houses, especially during the largest building programs of the eleventh and early twelfth centuries. It is perhaps significant to point out that the two foundational burials in Room 33 at Pueblo Bonito had only two whole vesselsone was a smudged brown ware bowl more typical of areas at the southern edge of the Chaco World (Mills et al. 2018), and the other was a Black Mesa-style bowl.

In comparison to other studies of regional styles in the Southwest and elsewhere, Chaco pottery provides some interesting contrasts. Recent work by Hegmon and colleagues (2021) in the southern Southwest demonstrated the convergence of spatial and stylistic boundaries for the Mimbres area and low representational diversity. Our Chaco example contrasts in having much greater representational heterogeneity; spatial boundedness was shared at the level of the great house community, but not shared by all great houses-even among some in close proximity. The Chaco case is also contrastive with the Mimbres region in that there is considerably more evidence for intracommunity and intraregional social inequality. At the intracommunity level, style seems to be shared much more frequently - as would be expected with high levels of cooperation-between elites in great houses and those in surrounding small houses. At the intraregional scale, however, we see that entire communities, and especially many great houses, had highly variable assemblages composed of a diversity of styles. Elites and nonelites living in great house communities outside of Chaco Canyon showed more representational diversity, which indicates multiple connections within the Chaco World rather than an adherence to a single style. We think that the variability in style choices made by residents of great houses is one way of looking at intraregional networks that represent different histories, alliances, and perhaps even competition among elites within the Chaco World.

As one of the well-known examples of social inequality in the Southwest, the Chaco World provides insights into the multiple ways elites and nonelites employed style. These insights may be a useful comparison to other areas of the world. The results also point to the importance of considering variation within the category of elites. Not all elites, even those in similarly sized great houses, can be considered as the same. Their spheres of control and influence varied across the social landscape of the Chaco World, as reflected by variation in the production and use of Dogoszhi-style painted ceramics. Current research in the social sciences has called for a breaking down of the category of "elites" to better understand how they operate within different fields (Cousin et al. 2018). Our analyses underscore appreciation for looking at heterogeneity among the Chaco World's great house occupants, such as the ways that they used style to convey differences in status and their variable engagements with each other.

Acknowledgments. Financial support was provided by NSF Awards \#1355374 (to Barbara Mills, University of Arizona) and \#1355381 (to Jeffery Clark, Archaeology Southwest). We especially thank Dennis Gilpin, Paul Reed, and Lori 
Reed for sharing ceramic data. We also thank the staff of many institutions that provided access to collections, including the American Museum of Natural History, Arizona State Museum, Arizona State University Archaeological Repository, Chaco Culture National Historic Park, Museum of New Mexico, Museum of Northern Arizona, Salmon Ruins Museum, School for Advanced Research, and the Navajo Nation. Photo permissions were facilitated by Julia Clifton (Museum of Indian Arts and Culture), Kim Besom (Grand Canyon National Park), Kelley Hays-Gilpin (Northern Arizona University), and Suzanne Eckert (Arizona State Museum). Thanks also to the three anonymous reviewers who provided useful comments on our submission.

Data Availability Statement. Data used in this article are available through cyberSW.org (https://cybersw.org). Data and code necessary to replicate the analyses and figures presented in this article are available at: https://github.com/ mpeeples2008/Dogoszhi_AmericanAntiquity.

Supplemental Material. For supplemental material accompanying this article, visit https://doi.org/10.1017/aaq.2021. 50.

Supplemental Table 1. Chaco Outlier Communities with Ceramic Data from Great Houses, Great Kivas, and Small Houses.

Supplemental Table 2. Black Mesa-Style Relative Frequency and Variance by Macroregion. Standard deviation and interquartile range are calculated only for regions with at least four sites and greater than $10 \%$ relative frequency of Black Mesa style.

Supplemental Table 3. Dogoszhi-Style Relative Frequency and Variance by Macroregion. Standard deviation and interquartile range are calculated only for regions with at least eight sites and greater than $10 \%$ relative frequency of Dogoszhi style.

\section{Notes}

1. Many archaeologists refer to this style as "Red Mesa style" because of the abundance of Red Mesa Black-on-white, but "Black Mesa style" has precedence (Plog 1980; Wasley 1959).

2. This is also an issue for a small number of assemblages from the Zuni/Cibola area where Puerco Black-on-white was used as a catchall type that included what researchers since the 1990s have divided into Puerco, Gallup, and Escavada black-on-whites. As a result, we may be slightly underrepresenting the frequency in the Cibola region.

\section{References Cited}

Allison, James R.

2008 Shinarump Red Ware and Other Red Ware Pottery: North and West of the Colorado River. Pottery Southwest 27(1):21-34.

Bellorado, Benjamin A.

2020 Leaving Footprints in the Ancient Southwest: Visible Indicators of Group Affiliation and Social Position in the Chaco and Post-Chaco Eras (AD 850-1300). $\mathrm{PhD}$ dissertation, School of Anthropology, University of Arizona, Tucson.

Betancourt, Julio L., Jeffrey S. Dean, and Herbert M. Hull 1986 Prehistoric Long-Distance Transport of Construction Beams, Chaco Canyon, New Mexico. American Antiquity 51:370-375.

Breternitz, David A.

1966 An Appraisal of Tree-Ring Dated Pottery in the Southwest. Anthropological Papers of the University of Arizona No. 10. University of Arizona Press, Tucson.

Breternitz, David A., Arthur H. Rohn Jr., and Elizabeth A. Morris

1974 Prehistoric Ceramics of the Mesa Verde Region. Museum of Northern Arizona Ceramic Series 5. Northern Arizona Society of Science and Art, Flagstaff.

Cameron, Catherine $\mathrm{M}$

2001 Pink Chert, Projectile Points, and the Chacoan Regional System. American Antiquity 66:79-101.

Cameron, Catherine M., and H. Wolcott Toll

2001 Deciphering the Organization of Production in Chaco Canyon. American Antiquity 66:5-13.

Carr, Christopher

1995 Building a Unified Middle-Range Theory of Artifact Design. In Style, Society, and Person: Archaeological and Ethnological Perspectives, edited by Christopher Carr and Jill E. Neitzel, pp. 151-170. Plenum Press, New York.

Christenson, Andrew

1994 A Test of Mean Ceramic Dating Using Well-Dated Kayenta-Anasazi Sites. Kiva 59:297-317.

Colton, Harold S.

1943 The Principle of Analogous Pottery Types. American Anthropologist 45:316-320.

1953 Potsherds: An Introduction to the Study of Prehistoric Southwestern Ceramics and Their Uses in Historic Reconstruction. Museum of Northern Arizona Bulletin No. 25. Northern Arizona Society of Science and Art, Flagstaff.

Cousin, Bruno, Shamus Khan, and Ashley Mears

2018 Theoretical and Methodological Pathways for Research on Elites. Socio-Economic Review 16:225249.

Crown, Patricia L.

2018 Drinking Performance and Politics in Pueblo Bonito, Chaco Canyon. American Antiquity 83:387-406.

Crown, Patricia L. (editor)

2020 The House of the Cylinder Jars: Room 28 in Pueblo Bonito, Chaco Canyon. University of New Mexico Press, Albuquerque.

Crown, Patricia L., and William J. Hurst

2009 Cacao Use in the Prehispanic American Southwest. PNAS 106:2110-2113.

Crown, Patricia L., and Wirt H. Wills

2003 Modifying Pottery and Kivas at Chaco: Pentimento, Restoration, or Renewal. American Antiquity 68:511532.

Crumley, Carole L.

1995 Heterarchy and the Analysis of Complex Societies. Archeological Papers of the American Anthropological Association 6:1-5.

DeBoer, Warren

1991 The Decorative Burden: Design, Medium, and Change. In Ceramic Ethnoarchaeology, edited by William A. Longacre, pp. 144-161. University of Arizona Press, Tucson. 
Doyel, David E., Cory D. Breternitz, and Michael P. Marshall 1984 Chacoan Community Structure: Bis sa'ani and the Chaco Halo. In Recent Research on Chaco Prehistory, edited by W. James Judge and John D. Schelberg, pp. 37-54. Reports of the Chaco Center No. 8. National Park Service, Albuquerque.

Elson, Christina M., and R. Jason Sherman

2013 Crema Ware and Elite Power at Monte Albán: Ceramic Production and Iconography in the Oaxaca Valley, Mexico. Journal of Field Archaeology 32:265-282.

Feinman, Gary, and Jill Neitzel

1984 Too Many Types: An Overview of Prestate Societies in the Americas. In Advances in Archaeological Method and Theory, edited by Michael B. Schiffer, Vol. 7, pp. 39-102. Academic Press, New York.

Fowles, Severin

2012 The Pueblo Village in an Age of Reformation (AD 1300-1600). In The Oxford Handbook of North American Archaeology, edited by Timothy R. Pauketat, pp. 631-644. Oxford University Press, New York.

Franklin, Hayward

2006 Primary Occupation Ceramics. In Thirty-Five Years of Archaeological Research at Salmon Ruins, New Mexico: 2, Ceramic Studies, edited by Paul F. Reed, pp. 419483. Center for Desert Archaeology, Tucson, Arizona; Salmon Ruins Museum, Bloomfield, New Mexico.

Goetze, Christine E., and Barbara J. Mills

1993 Classification Criteria for Types and Wares. In Across the Colorado Plateau: Anthropological Studies for the Transwestern Pipeline Project: 16, Interpretation of Ceramic Artifacts, by Barbara J. Milles, Christine E. Goetze, and Maria Nieves Zedeńo, pp. 21-85. Office of Contract Archaeology and Maxwell Museum of Anthropology, University of New Mexico, Albuquerque.

Guiterman, Christopher H., Thomas W. Swetnam, and Jeffrey S. Dean

2016 Eleventh-Century Shift in Timber Procurement Areas for the Great Houses of Chaco Canyon. PNAS 113:1186-1190.

Harris, Rachel Marie

2014 Comparative Analysis of Ceramics from Three Great Houses and One Small House Site in Southeast Utah. Master's thesis, Department of Anthropology, Brigham Young University, Provo, Utah.

Hayes, Alden C., and James A. Lancaster

1975 Badger House Community, Mesa Verde National Park. National Park Service, U.S. Department of the Interior, Washington, DC.

Hays-Gilpin, Kelley

1998 Decoration of Basketmaker Twined Sandals. In Prehistoric Sandals from Northeastern Arizona: The Earl H. Morris and Ann Axtell Morris Research, edited by Kelley Hays-Gilpin, Ann Cordy Deegan, and Elizabeth Ann Morris, pp. 81-120. Anthropological Papers of the University of Arizona No. 62. University of Arizona Press, Tucson.

Hays-Gilpin, Kelley A., and Eric Van Hartesveldt

1998 Prehistoric Ceramics of the Puerco Valley: The 1995 Chambers-Sanders Trust Lands Ceramic Conference. Museum of Northern Arizona Ceramic Series No. 7. Museum of Northern Arizona, Flagstaff.

Hegmon, Michelle

1992 Archaeological Research on Style. Annual Review of Anthropology 21:517-536.
1995 The Social Dynamics of Pottery Style in the Early Puebloan Southwest. Crow Canyon Archaeological Center, Cortez, Colorado.

Hegmon, Michelle, Jacob Freeman, Keith W. Kintigh, Margaret C. Nelson, Sarah Oas, Matthew A. Peeples, and Andrea Torvinen

2016 Marking and Making Differences: Representational Diversity in the U.S. Southwest. American Antiquity 81:253-272.

Hegmon, Michelle, Will G. Russell, Kendall Baller, Matthew A. Peeples, and Sarah Striker

2021 The Social Significance of Mimbres Painted Pottery in the U.S. Southwest. American Antiquity 86:23-42.

Heidke, James M., and Mary F. Ownby

2015 Prehistoric Pottery from La Villa, AZ T:12:148 (ASM): Dating, Technology, Provenance, Design, and Function with a Consideration of Ceramic Variability and a Model of Buff Ware Production. In Excavations at La Villa: Continuity and Change at an Agricultural Village, edited by Michael W. Lindeman, pp. 157252. Technical Report No. 2012-08. Desert Archaeology, Tucson, Arizona.

Judge, W. James

1991 Chaco: Current Views of Prehistory and the Regional System. In Chaco \& Hohokam: Prehistoric Regional Systems in the American Southwest, edited by Patricia L. Crown and W. James Judge, pp. 11-30. SAR Press, Santa Fe, New Mexico.

Kantner, John

2003a Preface: The Chaco World. Kiva 69:83-92.

2003b Rethinking Chaco as a System. Kiva 69:207-227. Lekson, Stephen H.

2007 Great House Form. In The Architecture of Chaco Canyon, New Mexico, edited by Stephen H. Lekson, pp. 7-44. University of New Mexico Press, Albuquerque.

2015 The Chaco Meridian: One Thousand Years of Political and Religious Power in the Ancient Southwest. 2nd ed. Rowman \& Littlefield, New York.

Mattson, Hannah V.

2016 Ornaments as Socially Valuable Objects: Jewelry and Identity in the Chaco and Post-Chaco Worlds. Journal of Anthropological Archaeology 42:122-139.

Mills, Barbara J., Matthew A. Peeples, Leslie D. Aragon, Benjamin A. Bellorado, Jeffery J. Clark, Evan Giomi, and Thomas $\mathrm{C}$. Windes

2018 Evaluating Chaco Migration Scenarios Using Dynamic Social Network Analysis. Antiquity 92:922939.

Morris, Craig

1995 Symbols to Power: Styles and Media in the Inka State. In Style, Society, and Person: Archaeological and Ethnological Perspectives, edited by Christopher Carr and Jill E. Neitzel, pp. 419-433. Plenum Press, New York.

Neitzel, Jill E.

1995 Elite Styles in Hierarchically Organized Societies: The Chacoan Regional System. In Style, Society, and Person: Archaeological and Ethnological Perspectives, edited by Christopher Carr and Jill E. Neitzel, pp. 393417. Plenum Press, New York.

Neitzel, Jill E., and Ronald L. Bishop

1990 Neutron Activation of Dogoszhi Style Ceramics: Production and Exchange in the Chacoan Regional System. Kiva 56:67-85 
Neitzel, Jill E., Hector Neff, Michael D. Glascock, and Ronald L. Bishop

2002 Chaco and the Production and Exchange of Dogoszhi-Style Pottery. In Ceramic Production and Circulation in the Greater Southwest, edited by Donna Glowacki and Hector Neff, pp. 47-65. Monograph 44. Cotsen Institute of Archaeology, University of California, Los Angeles.

Nelson, Ben A., Paul R. Fish, and Suzanne K. Fish

2017 Mesoamerican Connections. In The Oxford Handbook of Southwest Archaeology, edited by Barbara J. Mills and Severin Fowles, pp. 461-480. Oxford University Press, Oxford.

Newman, Mark J.

2010 Networks: An Introduction. Oxford University Press, Oxford.

Ortman, Scott G., Erin L. Baxter, Carole L. Graham, G. Robin Lyle, Lew W. Matis, Jamie A. Merewether, R. David Satterwhite, and Jonathan D. Till

2005 Crow Canyon Archaeological Center Laboratory Manual, Version 1.0. Crow Canyon Archaeological Center, Cortez, Colorado.

Plog, Stephen

1980 Stylistic Variation in Prehistoric Ceramics: Design Analysis in the American Southwest. Cambridge University Press, New York.

1989 The Sociopolitics of Exchange (and Archaeological Research) in the Northern Southwest. In The Sociopolitical Structure of Southwestern Societies, edited by Steadman Upham, Kent G. Lightfoot, and Roberta A. Jewett, pp. 129-148. Westview Press, Boulder, Colorado.

1990 Sociopolitical Implications of Stylistic Variation in the American Southwest. In The Uses of Style in Archaeology, edited by Margaret Conkey and Christine Hastorf, pp. 61-72. Cambridge University Press, Cambridge.

1995 Approaches to Style: Complements and Contrasts. In Style, Society, and Person: Archaeological and Ethnological Perspectives, edited by Christopher Carr and Jill E. Neitzel, pp. 369-392. Plenum Press, New York.

2003 Exploring the Ubiquitous through the Unusual: Color Symbolism in Pueblo Black-on-White Pottery. American Antiquity 68:665-695.

2015 Understanding Chaco: Past, Present, and Future. In Chaco Revisited: New Research on the Prehistory of Chaco Canyon, New Mexico, edited by Carrie C. Heitman and Stephen Plog, pp. 3-29. University of Arizona Press, Tucson.

Plog, Stephen, and Carrie Heitman

2010 Hierarchy and Social Inequality in the American Southwest, A.D. 800-1200. PNAS 107:19619-19626.

Plog, Stephen, and Julie Solometo

1997 The Never-Changing and the Ever-Changing: The Evolution of Western Pueblo Ritual. Cambridge Archaeological Journal 7:161-182.

Rautman, Alison E.

1998 Hierarchy and Heterarchy in the American Southwest: A Comment on McGuire and Saitta. American Antiquity 63:325-333.

Reed, Lori Stephens

2005 Ceramic Analysis Data. On file at Salmon Ruins Museum, Bloomfield, New Mexico. Analysis resulting from NSF Grant: Chacoan Expansion or Emulation of the Chacoan System? The Emergence of Aztec, Salmon, and Other Great House Communities in the Middle San
Juan. Manuscript on file, Archaeology Southwest, Tucson; Salmon Ruins Museum, Bloomfield, New Mexico.

2006 Middle San Juan Typological and Chronological Perspective. In Thirty-Five Years of Archaeological Research at Salmon Ruins, New Mexico: 2, Ceramic Studies, edited by Paul F. Reed, pp. 593-633. Center for Desert Archaeology, Tucson, Arizona; Salmon Ruins Museum, Bloomfield, New Mexico.

2007 Decoding Chacoan Ceramics from Aztec Ruins. In fulfillment of Western National Parks Association Grant No. 2006-01 and Aztec Accession No. 325. Manuscript on file, Aztec Ruins National Monument, Aztec, New Mexico.

2008 Tommy Site Ceramic Data. Manuscript and data on file, Totah Archaeological Project, San Juan College, Farmington, New Mexico.

Reed, Lori Stephens, and Joell Goff

2000 Tommy Site Midden Ceramic Data. Manuscript and data on file, Totah Archaeological Project, San Juan College, Farmington, New Mexico.

Reed, Lori Stephens, and Tori L. Myers

2006 New Research with Ceramic Data from Salmon Pueblo Rooms. In Thirty-Five Years of Archaeological Research at Salmon Ruins, New Mexico: 2, Ceramic Studies, edited by Paul F. Reed, pp. 635-694. Center for Desert Archaeology, Tucson, Arizona; Salmon Ruins Museum, Bloomfield, New Mexico.

Roberts, Frank H. H.

1927 The Ceramic Sequence in the Chaco Canyon, New Mexico, and Its Relation to the Cultures of the San Juan Basin. PhD dissertation, Department of Anthropology, Harvard University, Cambridge, Massachusetts.

Roberts, John M., Jr., Barbara J. Mills, Jeffery J. Clark, W. Randall Haas, Deborah L. Huntley, and Meaghan A. Trowbridge

2012 A Method for Chronological Apportioning of Ceramic Assemblages. Journal of Archaeological Science 39:1513-1520.

Rohman, Peter

2000 Chapter 12: 5MT5498. In MAPL - Multisite \& Component, N. New Mexico and SW Colorado, Volume 3. Woods Canyon Archaeological Consultants. Electronic document, http://woodscanyon.net/MAPL/Sites/ 5MT5498/introduction.htm, accessed October 21, 2020.

Russell, Will G., Sarah Klassen, and Katherine Salazar

2017 Lines of Communication: Mimbres Hachure and Concepts of Color. American Antiquity 83:1-19.

Saitta, Dean J., and Randall H. McGuire

1998 Dialectics, Heterarchy, and Western Pueblo Social Organization. American Antiquity 63:334-336.

Schortman, Edward M.

2014 Networks of Power in Archaeology. Annual Review of Anthropology 43:167-182.

Schortman, Edward M., Patricia A. Urban, and Marne Ausec

2001 Politics with Style: Identity Formation in Prehispanic Southeastern Mesoamerica. American Anthropologist 103:312-330.

Thibodeau, Allyson M., John T. Chesley, Joaquin Ruiz, David J. Killick, and Arthur Vokes

2012 An Alternative Approach to the Prehispanic Turquoise Trade. In Turquoise in Mexico and North America: Science, Conservation, Culture, and Collections, edited by Jonathan C. H. King, Caroline R. Cartwright, and Colin McEwan, pp. 65-74. Archetype, London. 
Toll, H. Wolcott

1985 Pottery, Production, and Public Architecture and the Chaco Anasazi System. PhD dissertation, Department of Anthropology, University of Colorado, Boulder. University Microfilms, Ann Arbor, Michigan.

1990 A Reassessment of Chaco Cylinder Jars. In Clues to the Past: Papers in Honor of William Sundt, edited by Meliha S. Duran and David T. Kirkpatrick, pp. 273305. Papers No. 16. Archaeological Society of New Mexico, Albuquerque.

Toll, H. Wolcott, Eric Blinman, and C. Dean Wilson

1992 Chaco in the Context of Ceramic Regional Systems. In Anasazi Regional Organization and the Chaco System, edited by David E. Doyel, pp. 147-157. Anthropological Papers No. 5. Maxwell Museum of Anthropology, Albuquerque, New Mexico.

Toll, H. Wolcott, and Peter J. McKenna

1997 Chaco Ceramics. In Ceramics, Lithics, and Ornaments of Chaco Canyon, Vol. 1, edited by F. Joan Mathien, pp. 17-215. Publications in Archeology 18G, Chaco Canyon Studies. National Park Service, Santa Fe, New Mexico.

Wallace, Henry D.

2001 Time Seriation and Typological Refinement of the Middle Gila Buff Ware Sequence: Snaketown through Soho Phases. In Grewe Archaeological Project: 2, Material Culture: Part I. Ceramic Studies, edited by David R. Abbott, pp. 177-261. Anthropological Papers No. 99-1. Northland Research, Flagstaff, Arizona.

Ware, John A.

2014 A Pueblo Social History: Kinship, Sodality, and Community in the Northern Southwest. SAR Press, Santa Fe, New Mexico.
Warren, A. Helene

1976 Technological Studies of the Pottery of Chaco Canyon. Manuscript on file at the Chaco Center, National Park Service, University of New Mexico, Albuquerque.

Wasley, William W.

1959 Cultural Implications of Style Trends in Southwestern Prehistoric Pottery: Basketmaker III to Pueblo II in West Central New Mexico. PhD dissertation, School of Anthropology, University of Arizona, Tucson.

Watson, Adam S., Stephen Plog, B. J. Culleton, Patricia A. Gilman, Steven A. LeBlanc, Peter M. Whiteley, S. Claramunt, and Douglas J. Kennett

2015 Early Procurement of Scarlet Macaws and the Emergence of Social Complexity in Chaco Canyon, NM. PNAS 112:8238-8243.

Windes, Thomas C

1977 Typology and Technology of Anasazi Ceramics. In Settlement and Subsistence along the Lower Chaco River, edited by Charles A. Reher, pp. 270-369. University of New Mexico Press, Albuquerque.

1984 A View of the Cibola Whiteware from Chaco Canyon. In Regional Analysis of Prehistoric Ceramic Variation: Contemporary Studies of the Cibola Whitewares, edited by Alan P. Sullivan and Jeffrey L. Hantman, pp. 94-119. Anthropological Papers No. 31. Arizona State University, Tempe.

Submitted December 18, 2020; Revised March 19, 2021; Accepted March 25, 2021 